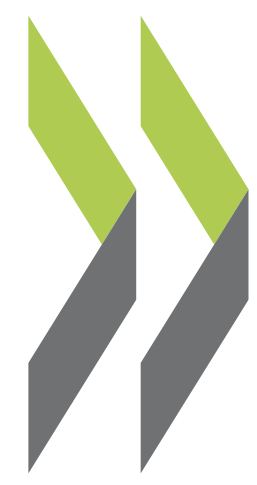

OECD Economics Department Working Papers No. 1251

Economic resilience: what role for policies?

Aida Caldera Sánchez,

Morten Rasmussen,

Oliver Röhn 
Organisation de Coopération et de Développement Économiques

Organisation for Economic Co-operation and Development

22-Jul-2015

ECONOMICS DEPARTMENT

English - Or. English

ECONOMIC RESILIENCE: WHAT ROLE FOR POLICIES?

ECONOMICS DEPARTMENT WORKING PAPERS NO. 1251

By Aida Caldera Sánchez, Morten Rasmussen and Oliver Röhn

OECD Working Papers should not be reported as representing the official views of the OECD or of its member countries. The opinions expressed and arguments employed are those of the author(s).

Authorised for publication by Christian Kastrop, Director, Policy Studies Branch, Economics Department.

All Economics Department Working Papers are available at www.oecd.org/eco/workingpapers

Complete document available on OLIS in its original format

This document and any map included herein are without prejudice to the status of or sovereignty over any territory, to the delimitation of international frontiers and boundaries and to the name of any territory, city or area. 
OECD Working Papers should not be reported as representing the official views of the OECD or of its member countries. The opinions expressed and arguments employed are those of the author(s).

Working Papers describe preliminary results or research in progress by the author(s) and are published to stimulate discussion on a broad range of issues on which the OECD works.

Comments on Working Papers are welcomed, and may be sent to the Economics Department, OECD, 2, rue André-Pascal, 75775 Paris Cedex 16, France, or by e-mail to eco.contact@oecd.org.

All Economics Department Working Papers are available at www.oecd.org/eco/workingpapers.

The statistical data for Israel are supplied by and under the responsibility of the relevant Israeli authorities. The use of such data by the OECD is without prejudice to the status of the Golan Heights, East Jerusalem and Israeli settlements in the West Bank under the terms of international law.

\section{(C) OECD (2015)}

You can copy, download or print OECD content for your own use, and you can include excerpts from OECD publications, databases and multimedia products in your own documents, presentations, blogs, websites and teaching materials, provided that suitable acknowledgment of OECD as source and copyright owner is given. All requests for commercial use and translation rights should be submitted to rights@oecd.org 


\section{Abstract/Resume \\ Economic Resilience: What Role for Policies?}

The global financial crisis highlighted the importance of strengthening the resilience of our economies to adverse shocks. In this paper, we take stock of studies carried out primarily within, but also outside the OECD, to better understand the role of macroeconomic and structural policies in spurring or mitigating the vulnerabilities that can lead to costly shocks, as well as the role of policies in mitigating the shock impact and speeding the recovery. Then we offer tentative insights on how policies can be geared to address vulnerabilities early on, mitigate the impact of shocks and speed recoveries, as well as highlight possible trade-offs that exist across policy areas.

JEL classification codes: E32; E44; E51; F47

Keywords: Resilience, vulnerabilities, imbalances, severe recessions, crises.

*********

\section{Résilience économique: Quel rôle pour les politiques ?}

La crise financière mondiale a mis en évidence l'importance de renforcer la résilience de nos économies face aux chocs défavorables. Cet article passe en revue les études réalisées principalement au sein, mais aussi en dehors de l'OCDE, afin de mieux comprendre les liens entre les politiques macroéconomiques et structurelles et les vulnérabilités pouvant entraîner de sévères récessions, ainsi que le rôle des politiques pour atténuer l'impact des chocs et accélérer la reprise. Ensuite, l'article propose quelques pistes de réflexion sur comment les politiques peuvent être adaptées pour répondre mieux aux vulnérabilités, atténuer l'impact des chocs et accélérer la reprise économique, toute en mettant en évidence les arbitrages possibles qui existent entre les domaines politiques.

Classification JEL: E32; E44; E51; F47

Mots clefs:: Résilience, vulnérabilités, déséquilibres, récessions sévères, crises. 


\section{TABLE OF CONTENTS}

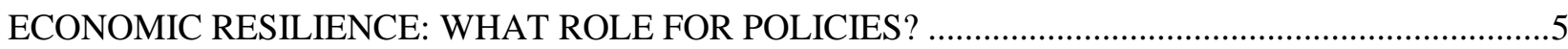

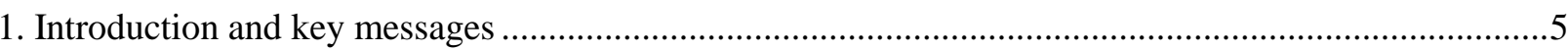

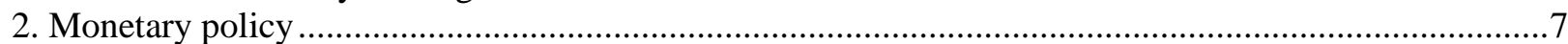

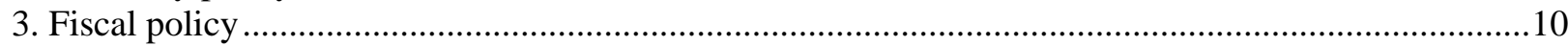

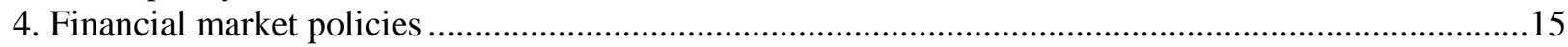

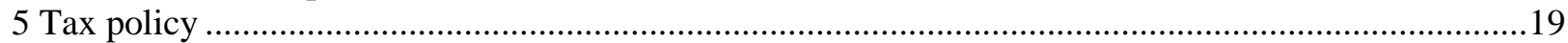

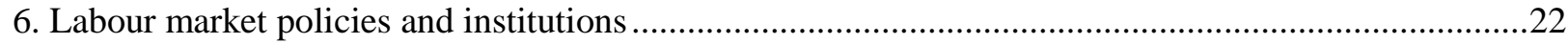

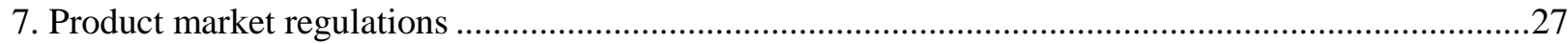

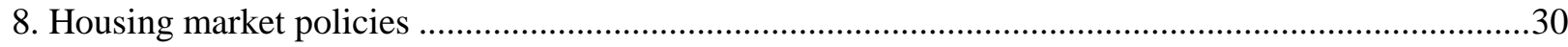

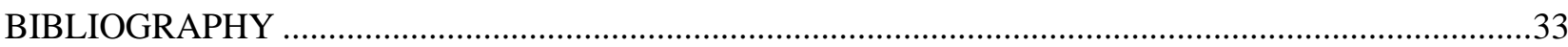

\section{Tables}

1. Empirical evidence on the linkages between monetary policy and resilience .................................9

2. Empirical evidence on the linkages between fiscal policy and resilience ......................................14

3. Empirical evidence on the linkages between financial market policies and resilience ....................17

4. Empirical evidence on the linkages between tax policy and resilience ..........................................21

5. Empirical evidence on the linkages between labour market policies and resilience ........................25

6. Empirical evidence on the linkages between product market regulations and resilience .................29

7. Empirical evidence on the linkages between housing market policies and resilience.......................32

A1. Synthesis table on the linkages between policies and the different dimensions of resilience ..........43

\section{Figures}

1. Automatic stabilisers cushion households' disposable income from shocks...................................11

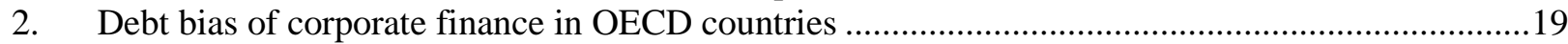

\section{Boxes}

Box 1. Effective discretionary policy: What does recent evidence tell us? 
ECO/WKP(2015)69

\title{
ECONOMIC RESILIENCE: WHAT ROLE FOR POLICIES?
}

\author{
By \\ Aida Caldera Sánchez, Morten Rasmussen and Oliver Röhn ${ }^{1}$
}

\section{Introduction and key messages}

1. Countries are subject to a wide variety of economic shocks, including financial crises, sovereign debt crises, commodity price fluctuations or volatility in the world economy. These shocks can increase risk and uncertainty for households, investors and governments, and when sufficiently large, can trigger crises and throw economies off their growth path and lead to long-lasting periods of stagnation. From a policy perspective it is therefore important to understand the factors that condition a country's resilience to adverse shocks, defined broadly as the capacity to contain potential vulnerabilities and reduce the probability of crises and enhance the capacity of the broader economy to cope with shocks.

2. This paper takes a first pass at reviewing what is known about how policies shape a country's economic resilience to shocks. It takes stock of studies carried out - primarily within, but also outside the $\mathrm{OECD},-$ to better understand the role of macroeconomic and structural policies in spurring or mitigating the vulnerabilities that can lead to costly shocks, as well as the role of policies in mitigating the shock impact and speeding the recovery.

3. The paper reviews work in two distinct areas. A first strand of work has assessed the capacity of an economy to resist to shocks and recover quickly (e.g. de Serres and Drew, 2004; Duval et al., 2007; Sutherland and Hoeller, 2013). This work defined a resilient economy as one that better withstands an adverse shock and returns back faster to the pre-shock trend growth rate (i.e. minimising the cumulative GDP loss relative to potential output). It investigated how structural policy settings - notably product market regulations and labour market institutions - impact on resilience by interacting with the transmission of shocks as well as by affecting their amplification and persistence. A second strand of OECD work has examined the influence of structural policy settings on a country's risk of suffering a banking crisis (Ahrend and Goujard, 2012a,b; 2011). This is part of a large literature assessing the type of vulnerabilities (or "early warnings") that make countries more likely to be hit by costly events or crises, such as currency, banking and debt crises (e.g. Frankel and Rose, 1996; Kaminsky et al., 1998). These are vast areas of research and the literature review conducted in this paper is necessarily selective.

4. A number of key messages emerge from this literature review:

- Policies can help to mitigate the build-up of vulnerabilities in the boom phase of the cycle. For instance, macro-prudential regulation can limit banking sector instability and excessive procyclicality. Minimising the distortions in tax policies due to special treatment of housing or the bias towards corporate debt, can help to reduce the risk of asset price bubbles. By addressing vulnerabilities early on policies can also mitigate the costs of future crises. For example, the

1. Aida Caldera Sánchez and Oliver Röhn are members of the Economics Department of the OECD. Morten Rasmussen works for Danmarks Nationalbank. They would like to thank Mikkel Hermansen, Christian Kastrop, Jean-Luc Schneider and Alain de Serres for helpful comments and Caroline Abettan for technical and editorial assistance. 
accumulation of fiscal surpluses during boom periods can enable aggressive fiscal stimulus in the event of a major downturn.

- Macroeconomic policies play a key role in mitigating the shock impact and speeding the recovery in the aftermath of a crisis. Expansionary monetary policy helps shorten recessions by boosting demand. Its effectiveness, however, depends on the type of shock. Monetary policy is typically less effective in a financial crisis, when the financial sector is functioning less well and private sector balance sheets are impaired. There also limits about how long expansionary monetary policy can be kept in place to support recoveries, without fuelling additional risks. On the fiscal side, effective countercyclical policy responses require sufficient fiscal space, including low debt and deficit levels combined with a track record of fiscal prudence to borrow at acceptable rates in times of crises.

- Structural policy settings play a key role in enhancing the resilience of economies to shocks through several channels: interacting with macroeconomic policies, affecting the speed of wage and price adjustment, and influencing the reallocation of resources across firms and sectors in response to shocks. For instance, rigid labour market policies, notably overly stringent employment protection, can cushion the impact of adverse shocks, but also slow the recovery by hampering labour reallocation. Active labour market policies can cushion the impact of a shock on the economy by facilitating the retraining of workers and their reallocation to new jobs. Likewise, flexible housing markets can facilitate mobility by allowing workers to move where jobs are available. However, housing markets that respond very quickly to increased demand through greater building activity can lead to cyclical swings. Finally, less restrictive product market regulations can help lower the impact and reduce the persistence of shocks.

- Identifying policy tools to enhance overall resilience is complicated by the existence of trade-offs and interactions in both macroeconomic and structural policy settings. For example, in times of crisis, policies aim to reduce the severity of the downturn and stimulate the recovery, but the policy response to the crisis may have unintended consequences by increasing vulnerabilities down the road. For instance, most OECD countries increased public spending and cut taxes to fight rapidly increasing unemployment during the global financial crisis. The fiscal stimulus increased government debt ratios, which may have raised public sector vulnerabilities, especially in countries with initially high debt ratios. Monetary policy has been extremely loose during the global financial crisis and unconventional tools have been applied in a number of countries to stimulate the slow recovery. The build-up of central banks' balance sheets and the resulting ample liquidity have raised concerns that the policy response is sowing the seeds of a new crisis by creating new vulnerabilities. Moreover, the extensive government bailouts to distressed financial institutions during the crisis, while essential to prevent a financial sector meltdown, may lead to future moral hazard behaviour.

- Policies that may be good for resilience may also face a trade-off with long-term growth objectives. For example, higher ratios of capital to assets within banks can help weather a crisis. However, beyond a certain point, a large storage of capital may hinder growth by limiting the funds available for lending.

5. This paper is part of a stream of work to develop a framework to assess the economic resilience of OECD member countries. In a companion paper, Röhn et al. (2015) discuss the source and nature of potential vulnerabilities in OECD countries that can lead to costly economic crises. Based on the most recent evidence from the early warning literature and lessons learned from the global financial crisis, the paper proposes a new dataset of more than 70 vulnerability indicators that could be monitored to assess country risks in OECD economies. The indicators are grouped into five domestic areas: i) financial sector 
imbalances, ii) non-financial sector imbalances, iii) asset market imbalances, iv) public sector imbalances and v) external sector imbalances. An additional international "spillovers, contagion and global risks" category aims at capturing vulnerabilities that could transmit from one country to another through financial, trade or confidence channels. Another companion paper (Hermansen and Röhn, 2015) provides empirical evidence on the usefulness of the set of vulnerability indicators to correctly signal severe recessions while avoiding false alarms. They find that the majority of indicators for which sufficiently long time series exists would have helped to predict severe recessions, as well as crises (banking, currency and sovereign debt crises) in the 34 OECD economies and Latvia between 1970 and 2014.

6. This paper is organised along policy areas. Sections 2 and 3 discuss monetary and fiscal policy respectively. Section 4 focusses on financial market policies. Sections 5 to 8 review the links between structural policies and resilience, including tax policy (Section 5), labour market policies and institutions (Section 6), product market policies (Section 7) and housing policies (Section 8). After each section a table provides an inventory of the selected studies outlining the results, the methodology and the time and country sample. Table 1 in the Appendix provides a synthesis of the literature review of the impact of policies on vulnerabilities, resistance and recovery by policy area.

\section{Monetary policy}

\section{Monetary policy and the build up of vulnerabilities}

7. Accommodative monetary policies, especially when in place for extended periods, have been linked to credit booms and excessive risk taking. Evidence suggests that low policy rates are associated with credit booms in both advanced and emerging economies (e.g. Elekdag and Wu, 2011). Low policy rates bring down lending rates and the costs of borrowing, which could fuel financial imbalances as it boosts asset prices and incentivises risk taking and potentially excessive borrowing. Such imbalances can lead to a misallocation of resources and lower economic efficiency. Moreover, the bursting of credit and asset-price bubbles is often followed by downturns with sharp declines in economic activity (Mishkin, 2011). This begs the question of whether monetary policy should try to pop or slow the growth of possibly developing financial and asset bubbles to mitigate their potential economic costs (e.g. Ahrend et al., 2008; Bayoumi et al., 2014; Sutherland et al., 2010).

8. Whether monetary policy should react to the build-up of credit and asset price bubbles is a long standing debate that is not yet settled (Woodford, 2012; Svensson, 2012a). One view is that monetary policy is not well suited for preventing such imbalances (e.g. Bayoumi, 2014; Bernanke, 2011; Svensson, $2012 b$ ). Because of its broad reach, monetary policy is too blunt as it would entail large collateral damage to activity and inflation. These authors argue that the consequences of financial distortions are best addressed through targeted microprudential and macroprudential tools that can reduce incentives for risk taking and help to build buffers ex ante. On the other hand, some authors (Mishkin, 2011; White, 2009) argue that with prudential measures being relatively new and untested, especially in advanced economies, the role of monetary policy in "leaning against" the build-up of vulnerabilities cannot be dismissed right away and should be an option to stop the most dangerous imbalances, notably credit bubbles.

9. Using monetary policy to deal with imbalances is not always feasible. For individual members of a monetary union, using monetary policy to fight asset price booms is challenging when asset price cycles are not well synchronised. In small open economies, tightening monetary policy to address imbalances may not be effective because raising interest rates would encourage capital inflows that could fuel a credit boom. 


\section{Monetary policy: shock mitigation and recovery}

10. Monetary policy is generally viewed as the first line of defence in stabilising the economy during a downturn. The conventional wisdom is that in a typical downturn monetary policy is more effective for demand management purposes than discretionary fiscal policy, as monetary policy does not suffer from implementation lags compared to discretionary fiscal policy. Empirical research does support this conventional wisdom and suggest that monetary policy has been consistently timely and countercyclical during downturns in G7 economies, while fiscal actions have been mostly delayed and procyclical in continental European countries and Japan, but not in Anglo-Saxon countries (See Leigh and Stehn, 2009 and references therein).

11. Empirical evidence further suggests that monetary policy is typically effective. Easy monetary policy during downturns does lead to faster recoveries after "normal" downturns (Bech et al., 2012; Kannan et al., 2009). However, monetary policy is less effective in a financial crisis, when private sector balance sheets and the monetary policy transmission channel are impaired (Borio, 2012; Bech et al., 2012; Kannan et al., 2009). There are at least two reasons why monetary policy is less effective in a financial crisis. First, financial crises are typically characterised by a high share of overly indebted economic agents, who do not wish to borrow in order to spend. Second, a damaged financial system is less effective in transmitting the policy stance to the rest of the economy (e.g. Rawdanowicz et al., 2015). The recent global financial crisis is a good example of how money markets can freeze during a crisis impeding banks short-term financing. Frozen credit markets coupled with weakened banks' balance sheets, impaired the transmission of lower policy rates to bank lending costs. This suggests that during a financial crisis short-term policy rates might need to be sharply reduced and, in some cases accompanied by unconventional monetary policy and discretionary fiscal policy, to effectively boost aggregate demand, as during the global financial crisis.

12. Pursuing a highly accommodative monetary policy over a prolonged period may create vulnerabilities down the road leading to policy trade-offs. During the global financial crisis, unconventional monetary policy measures were justified to prevent the harmful effects of financial system implosion on the real economy (e.g. Borio, 2012; Mishkin, 2009). However, extremely easy monetary policy conditions, and in particular the unprecedented increase in central banks' balance sheets can lead to risks. For instance, protracted monetary policy easing can delay the necessary balance sheet adjustments and prolong economic weakness (e.g. Borio, 2012; Bouis et al., 2013; Borio and Disyatat, 2010). There is also a number of risks related to increased balance sheets, including excessive credit expansion, financial market distortions or sovereign debt management conflicts (Caruana, 2012). And, if monetary policy is not viewed as an adequate tool to pre-empt the build-up of imbalances and bubbles (or "lean against the wind") then the result is an asymmetric stance of policy, with a bias on the side of loosening and associated risks of moral hazard. 
ECO/WKP(2015)69

Table 1. Empirical evidence on the linkages between monetary policy and resilience

\begin{tabular}{|c|c|c|c|c|c|c|c|c|c|c|c|c|}
\hline \multirow[b]{2}{*}{ Policy } & \multicolumn{4}{|c|}{ Vulne rability } & \multicolumn{4}{|c|}{ Resistance } & \multicolumn{4}{|c|}{ Recovery } \\
\hline & Results & Method & Sample & Study & Results & Method & Sample & Study & Results & Method & Sample & Study \\
\hline \multirow[t]{2}{*}{\begin{tabular}{|l|} 
Monetary \\
policy \\
interest \\
rates
\end{tabular}} & & & & & $\begin{array}{l}\text { Monetary policy interest rates } \\
\text { have been consistently timely } \\
\text { and strongly countercyclic al in } \\
\text { downturns. }\end{array}$ & VAR & $\begin{array}{l}\text { G7 } \\
\text { countries, } \\
\text { 1980Q1- } \\
\text { 2007Q4 }\end{array}$ & $\begin{array}{l}\text { Leigh and } \\
\text { Stehn (2009) }\end{array}$ & $\begin{array}{l}\text { Easy monetary policy } \\
\text { during 'normal' downturns } \\
\text { (not financial crisis) lead to } \\
\text { stronger recovery. }\end{array}$ & $\begin{array}{l}\text { Cross } \\
\text { section } \\
\text { regressions }\end{array}$ & $\begin{array}{l}24 \\
\text { developed } \\
\text { countries, } \\
1960 \text { 's- 2016 }\end{array}$ & $\begin{array}{l}\text { Bech et } \\
\text { al. (2012) }\end{array}$ \\
\hline & & & & & $\begin{array}{l}\text { Countercyclical monetary policy } \\
\text { shortens recessions, but its } \\
\text { effectiveness is limited in } \\
\text { financial crises. }\end{array}$ & $\begin{array}{l}\text { Duration } \\
\text { analysis }\end{array}$ & $\begin{array}{l}21 \text { OECD } \\
\text { countries, } \\
1960-2007\end{array}$ & $\begin{array}{l}\text { Kannan et } \\
\text { al. (2009) }\end{array}$ & $\begin{array}{l}\text { Reductions in nominal and } \\
\text { real interest rates beyond } \\
\text { that implied by the Taylor } \\
\text { rule strengthen economic }\end{array}$ & $\begin{array}{l}\text { Duration } \\
\text { analysis }\end{array}$ & $\begin{array}{l}21 \text { OECD } \\
\text { countries, } \\
1960-2007\end{array}$ & $\begin{array}{l}\text { Kannan } \\
\text { et al. } \\
\text { (2009) }\end{array}$ \\
\hline \multirow[t]{3}{*}{$\begin{array}{l}\text { Central } \\
\text { bank } \\
\text { balance } \\
\text { sheets }\end{array}$} & $\begin{array}{l}\text { Financial sector } \\
\text { imba lances: Vulnerability to } \\
\text { international bank balance } \\
\text { sheet shocks is lower when } \\
\text { abundant global liquidity is } \\
\text { provided by central banks. }\end{array}$ & $\begin{array}{l}\text { Panel } \\
\text { regressions }\end{array}$ & $\begin{array}{l}184 \\
\text { developed } \\
\text { and } \\
\text { developing } \\
\text { economies, } \\
\text { 1970-2009 }\end{array}$ & $\begin{array}{l}\text { Ahrend } \\
\text { and } \\
\text { Goujard } \\
(2012 a)\end{array}$ & $\begin{array}{l}\text { Central banks' asset purchase } \\
\text { programmes compressing the } \\
\text { long-term yield spread are } \\
\text { powerful on output growth and } \\
\text { inflation when the short interest } \\
\text { rate is constrained by the zero } \\
\text { lower bound. }\end{array}$ & $\begin{array}{l}\text { Bayesian } \\
\text { time-varying } \\
\text { parameter } \\
\text { structural } \\
\text { VAR }\end{array}$ & $\begin{array}{l}4 \text { countries, } \\
2007-2009\end{array}$ & $\begin{array}{l}\text { Baumeister } \\
\text { and Benati } \\
(2010)\end{array}$ & & & & \\
\hline & & & & & $\begin{array}{l}\text { Exogenous increases in central } \\
\text { bank balance sheets at the zero } \\
\text { lower bound lead to temporary } \\
\text { rise in economic activity and } \\
\text { consumer prices. }\end{array}$ & PanelVAR & $\begin{array}{l}8 \text { countries, } \\
\text { January } \\
2008-J u n e \\
2011\end{array}$ & $\begin{array}{l}\text { Gambacorta } \\
\text { et al. (2014) }\end{array}$ & & & & \\
\hline & & & & & $\begin{array}{l}\text { Real growth in the broad money } \\
\text { base is a powerful tool for } \\
\text { recovery in industrial countries, } \\
\text { but not in developing countries. }\end{array}$ & $\begin{array}{l}\text { Panel } \\
\text { regressions }\end{array}$ & $\begin{array}{l}197 \\
\text { countries, } \\
1960-2005\end{array}$ & $\begin{array}{l}\text { Cerra et al. } \\
(2008)\end{array}$ & & & & \\
\hline \multirow[t]{2}{*}{$\begin{array}{l}\text { Exchange } \\
\text { rate regime }\end{array}$} & $\begin{array}{l}\text { Financial sector } \\
\text { imba lances: No evidence } \\
\text { that fixed, floating or } \\
\text { intermediate exchange rate } \\
\text { regimes are more prone to } \\
\text { systemic banking crises, when } \\
\text { countries are hit by bank } \\
\text { balance sheet shocks. }\end{array}$ & $\begin{array}{l}\text { Panel } \\
\text { regressions }\end{array}$ & $\begin{array}{l}184 \\
\text { developed } \\
\text { and } \\
\text { developing } \\
\text { economies, } \\
1970 \text { to } \\
2009\end{array}$ & $\begin{array}{l}\text { Ahrend } \\
\text { and } \\
\text { Goujard } \\
\text { (2012a) }\end{array}$ & \multirow[t]{2}{*}{$\begin{array}{l}\text { A floating exchange rate regime } \\
\text { facilitates a quicker rebound } \\
\text { from recessions than fixed and } \\
\text { intermediate exchange rate } \\
\text { regimes, even when it is not the } \\
\text { best regime for long- term } \\
\text { growth. }\end{array}$} & \multirow[t]{2}{*}{$\begin{array}{l}\text { Panel } \\
\text { regressions }\end{array}$} & \multirow[t]{2}{*}{$\begin{array}{l}197 \\
\text { countries, } \\
1960-2005\end{array}$} & \multirow[t]{2}{*}{$\begin{array}{l}\text { Cerra et al. } \\
(2008)\end{array}$} & & & & \\
\hline & $\begin{array}{l}\text { External sector } \\
\text { imba la nces: Being in a } \\
\text { currency union does not lower } \\
\text { the probability of a sudden stop } \\
\text { or a current account reversal. } \\
\text { Countries in a currency union } \\
\text { have suffered more from } \\
\text { external shocks than flexible } \\
\text { exchange rate countries. }\end{array}$ & $\begin{array}{l}\text { Panel } \\
\text { regressions }\end{array}$ & $\begin{array}{l}157 \\
\text { countries, } \\
1970-2001\end{array}$ & $\begin{array}{l}\text { Edwards } \\
\text { (2006) }\end{array}$ & & & & & & & & \\
\hline
\end{tabular}




\section{Fiscal policy}

\section{Fiscal policy frameworks to reduce vulnerabilities}

13. Medium-term fiscal frameworks including well-designed fiscal rules can assist fiscal policy in becoming more sustainable, transparent, predictable and counter-cyclical (Pain and Roehn, 2011; Sutherland and Hoeller, 2013) and hence reduce the build-up of public sector vulnerabilities. In particular, medium-term expenditure rules offer a way of limiting boom-bust spending cycles by setting a multi-year plan or ceiling for government expenditure and ensuring that stronger than expected revenues are saved rather than spent. And, by building up reserves during expansionary phases of the cycle, expenditure rules can help to create room for discretionary stimulus and the unconstrained functioning of automatic stabilisers in a downturn.

14. Establishing an independent fiscal council (IFC) can be an important means of strengthening the compliance with announced fiscal targets and help depoliticising fiscal policy (Hagemann, 2011; Alesina and Giavazzi, 2013). By fostering accountability, fiscal councils can encourage policymakers to deliver more viable and more countercyclical policies (Debrun et al., 2012). The number of countries setting up fiscal councils has been growing over recent years following OECD and other institutions advice.

15. Fiscal frameworks can also make fiscal policy decisions more robust to budgetary uncertainty. For instance, asset price related tax revenue surprises have been an important source of bias in the assessment of structural budget balances and may have contributed to fuelling unsustainable booms (Roehn et al. 2015). Recent OECD work shows possible ways to adjust the budget balances for asset-price cycles (Price and Dang, 2011). Beyond this, uncertainties about the cyclically-adjusted budget balance can also arise from a range of other sources, such as uncertainty about the output gap and revisions to revenue and spending items. These uncertainties should be explicitly taken into account in the budget process. And with public finances in many countries now exposed to contingent liabilities arising from guarantees extended to the financial sector, regular stress-testing of government deficit and debt positions would be warranted.

\section{Fiscal policy: shock mitigation and recovery}

16. Fiscal policy can contribute to mitigate a downturn through two main channels (Debrun and Kapoor, 2010). First, fiscal policy mitigates shocks without any deliberate action through the so-called automatic stabilisers, which arise from parts of the fiscal system that naturally vary with changes in economic activity, most notably unemployment related expenditure. Second, through discretionary fiscal policy governments can deliberately adjust government spending, taxes or transfers to stimulate aggregate demand and mitigate a downturn.

\section{Automatic stabilisers}

17. Empirical evidence has indeed shown that automatic stabilisers help smooth output fluctuations, though their effectiveness varies across countries depending on their strength (Debrun and Kapoor, 2010; In 't Veld et al., 2012). The strength of the automatic stabilisers depends on several factors including the size of the public sector, the cyclicality of the tax base, the design of the public social security system, and the progressivity of the tax system (e.g. In 't Veld et al., 2012; van den Noord, 2000). Among OECD economies, automatic stabilisers tend to be particularly strong in Denmark, Belgium or Germany (Figure 1). 
Figure 1. Automatic stabilisers cushion households' disposable income from shocks

\section{Percentage of shock absorbed by tax benefit system}

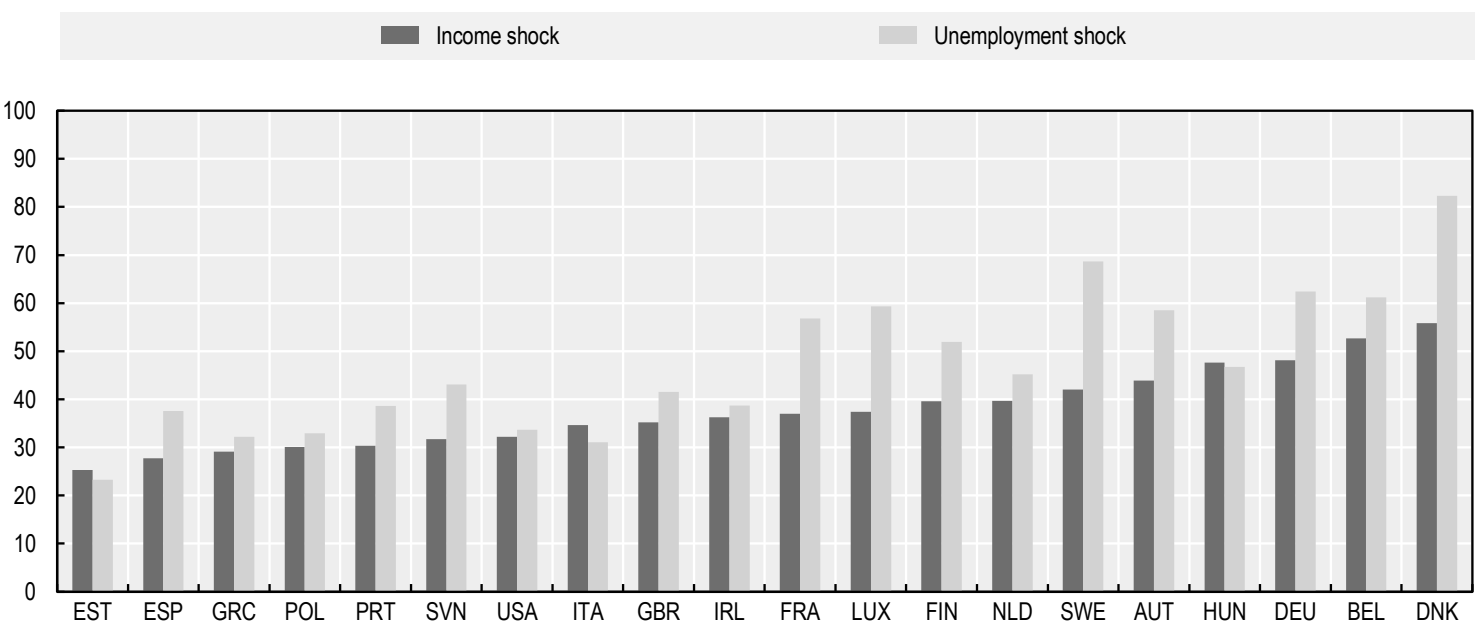

Note: The size of the automatic stabilisers is a measure of the implicit insurance on disposable income by the tax benefit system. The higher the coefficient, the stronger the stabilisation effect. For instance a coefficient of $40 \%$ implies that $40 \%$ of a shock to gross income (unemployment) is absorbed by the public budget and only $60 \%$ of the shock is transmitted into disposable income. The income changes are simulated based on EUROMOD (EU countries) and TAXSIM (United States). The income shock is simulated by a proportional decrease in gross income by $5 \%$ for all households, whereas the unemployment shock is simulated by an increase in the unemployment rate corresponding to a decrease in total household income by $5 \%$.

Source: Dolls et al. (2012).

18. Relying on automatic stabilisers as the only channel of fiscal stabilisation in a downturn has limits and drawbacks. First, automatic stabilisers may be insufficient in the case of acute recessions, or when other policy instruments or consumption smoothing opportunities are constrained (e.g. Debrun and Kapoor, 2010; Sutherland et al., 2010). Second, even if automatic stabilisers could be strengthened to play a more substantial role in smoothing the cycle in countries where they are relatively small, however, to the extent that the effectiveness of the stabilisers increases with the size of the public sector and the level of taxation there is a potential trade-off between increasing macroeconomic stability and boosting economic efficiency (Debrun and Kapoor, 2010; Blanchard et al., 2010).

19. Automatic stabilisers can nonetheless be enhanced to mitigate the negative impacts of downturns without hurting economic efficiency by making them more contingent on the state of the economy (e.g. Sutherland and Hoeller, 2013). There are several policies for doing so. One option is to link the generosity of unemployment insurance schemes to unemployment rates or other labour market conditions, so they become more generous when unemployment is high, as is done in Canada and Israel (Fall et al., 2014). Another option is to automatically link spending on active labour market policies to labour market conditions, as is done in Australia, Denmark and Switzerland (OECD, 2009b). A third option is to have short-time working schemes in place ready to be activated quickly when needed, as it was done during the global financial crisis in Germany and Austria. The general principle is to have programmes allowing for a timely adjustment in times of crisis, but also with sufficient built-in withdrawal mechanisms or incentives to minimise the risks that they maintain resources in non-viable or low-productivity firms or sectors and hurt growth in the long run. 


\section{Discretionary fiscal policy}

20. The second channel through which fiscal policy can be used to mitigate downturns is via discretionary fiscal policy. For normal economic downturns there is a broad consensus that monetary policy and automatic stabilisers should be the first line of defence rather than discretionary fiscal policy (Blanchard and Leigh, 2013; Cottarelli et al., 2014). There are a number of reasons for this. Evidence suggests that fiscal multipliers are typically positive, but small, and there is even some evidence of negative fiscal multipliers (Blanchard and Leigh, 2013; OECD, 2009a). Moreover, lags in the design and implementation of discretionary fiscal policy, together with the short length of recessions typically means that fiscal measures come too late: providing stimulus during the recovery rather than in the downturn. Finally, there is also a concern that policymakers may respond in an asymmetric manner, easing fiscal policy in downturns and not tightening sufficiently in upturns, implying a permanent increase in the public debt-to-GDP-ratio with potentially adverse consequences for fiscal sustainability and long term growth.

21. Discretionary fiscal policy may, however, be appropriate under special circumstances (Box 1). Fiscal multipliers are larger when monetary policy is constrained by the zero lower bound (ZLB) on nominal interest rates (Coenen et al., 2012; Blanchard and Leigh, 2013), the channels of monetary policy are impeded by a weak financial sector (Corsetti et al., 2012), or the economy is in a recession (Auerbach and Gorodnichenko, 2012).

\section{Box 1. Effective discretionary policy: What does recent evidence tell us?}

A new wave of research on the size of fiscal multipliers triggered by the financial crisis suggests that, under "special" circumstances, discretionary fiscal policy can have powerful effects on the economy in the short run (e.g. Alesina and Giavazzi, 2013; Blanchard and Leigh, 2013; Minseshima et al., 2014; Sutherland et al., 2010). A number of lessons can be drawn from this new wave of research:

- Initial fiscal space: The scope for fiscal stimulus depends on the initial fiscal space a government has available for new spending or tax cuts. Low government debt levels and sustainable public finances provide room for fiscal policy to address large adverse shocks (Sutherland et al., 2010).

- Size of automatic stabilisers: Automatic stabilisers tend to dampen the effect of discretionary fiscal stimulus through the growth channel: a fiscal stimulus increases growth, which leads to higher taxes and lower transfers, hence reducing the fiscal multiplier (Mineshima et al., 2014).

- Trade openness of an economy: The more open an economy is, the less it will benefit from the domestic demand expansion as the expansion will "leak out" through higher imports (Spilimbergo et al., 2008; Sutherland et al., 2010). OECD evidence indeed suggests that fiscal multipliers are smaller for more open economies reflecting import leakage (OECD, 2009a).

- The exchange rate regime: A country with a flexible exchange rate regime tends to have smaller fiscal multipliers than a country with a fixed regime because of the different monetary policy responses to a fiscal expansion (Mineshima et al., 2014). Under a flexible exchange rate regime, if the central bank does not change its monetary policy stance in response to a fiscal expansion, output will increase, interest rates will raise and foreign capital will flow in. This will result in an appreciation of the real exchange rate and a reduction of net exports (leakages). By contrast, under a fixed exchange rate regime, the central bank would have to expand the money supply to mitigate the appreciation pressures, resulting in a new equilibrium with larger output and unchanged interest rates.

- The monetary policy stance: Ideally, the fiscal position should complement monetary policy, so that the two main tools of macroeconomic stabilisation work together and not in opposite directions. The efficacy of discretionary fiscal policy increases if monetary policy is accommodative during a temporary fiscal expansion (Cottarelli et al., 2014). In particular, when interest rates are constrained by the zero lower bound, discretionary fiscal policy can be highly effective as a stabilisation tool (Coenen et al., 2012; Blanchard and Leigh, 2013). 
- Medium term fiscal sustainability concerns: The scope for expansionary fiscal policy may be limited when long-run fiscal constraints are significant. An increase in government spending (or tax cuts) in countries with high debt levels may act as a signal that fiscal tightening will be required in the near future. The anticipation of such adjustment could have a contractionary effect - through for instance adverse effects on financial markets, interest rates and/or consumer spending - that would offset short term expansionary effects. OECD evidence indeed suggests that Ricardian behaviour, implying that fiscal stimulus is offset by an increase in private sector savings, is likely to be stronger when governments are highly indebted (Roehn, 2010).

- Development of the economy: fiscal multipliers tend to be smaller in emerging economies than in advanced economies (IMF, 2008 and Ilzeztzki et al., 2011). This could be due to credibility issues, especially related to debt concerns, triggering an adverse interest rate response that would offset fiscal stimulus.

- $\quad$ Fiscal stimulus timeliness: For stimulus spending to affect the economy during a downturn, policymakers have to be quick to identify the downturn and to approve additional stimulus spending. Projects must be able to be implemented quickly ("shovel-ready") not requiring significant planning, research, and development. Stimulus that comes too late will not help support economic activity in the near term, and it could be destabilising if it comes at a time when growth is already improving. Finally, any stimulus should be explicitly temporary to avoid overheating and a ratcheting up of debt.

- $\quad$ Fiscal stimulus package design: Under normal circumstances, the largest short-run impact on aggregate demand is likely to come from government spending measures rather than those related to transfers or tax cuts (e.g. Mineshima et al., 2014). This is largely because spending measures have a direct impact on aggregate demand while revenue measures only impact demand indirectly. Among spending measures, OECD evidence suggests public investment is the most powerful instrument, as there is no offset of public investment via private agents' saving (Roehn, 2010).

- The state of the economy: Auerbach and Gorodnichenko (2012) find that fiscal multipliers are larger in downturns than in expansions. This is partly because during a recession government spending is less likely to cause an increase in the interest rate and crowd-out private consumption and investment. In addition, the proportion of liquidity constrained households and firms grows during recessions (Gali et al., 2007).

Fiscal frameworks:

22. Fiscal frameworks that keep public finances on a sustainable path and hence reduce vulnerabilities can create more fiscal space in good times to be able to react to large adverse negative shocks. The failure to attain sound public finances in the run-up to the crisis constrained the fiscal response in several countries during the crisis (Pain and Roehn, 2011). It also created strong pressures to consolidate during the downturn risking delaying and slowing the recovery.

23. Fiscal rules need to strike a balance between being sufficiently binding to be useful and sufficiently flexible in unusual times, without compromising credibility (Pain and Roehn, 2011; Schick, 2010). Simple balanced-budget rules that force governments to cut spending when revenues fall during a downturn can be destabilising. Similarly, excessively-rigid expenditure rules might inhibit necessary discretionary stimulus in severe downturns. And simply suspending fiscal rules at times of crisis, as many countries have done, has potentially lasting adverse consequences for their credibility. If credibility is to be underpinned, it is important to define the conditions under which the fiscal rule can be suspended temporarily. 
Table 2. Empirical evidence on the linkages between fiscal policy and resilience

\begin{tabular}{|c|c|c|c|c|c|c|c|c|c|c|c|c|}
\hline \multirow{4}{*}{\begin{tabular}{|l|} 
Policy \\
Automatic \\
stabilisers
\end{tabular}} & \multicolumn{4}{|c|}{ Vulnerability } & \multicolumn{4}{|c|}{ Resistance } & \multicolumn{4}{|c|}{ Recovery } \\
\hline & Results & Method & Sample & Study & Results & Method & Sample & Study & Results & Method & Sample & Study \\
\hline & $\begin{array}{l}\text { Non- financial sector } \\
\text { imbalanc es: Taking both the } \\
\text { spending and income side into } \\
\text { account the overall size of } \\
\text { government (positive } \\
\text { correlated with the size of } \\
\text { automatic stabilisers) in the } \\
\text { economy may reach levels that } \\
\text { hinder growth. }\end{array}$ & $\begin{array}{l}\text { Panel } \\
\text { regressions }\end{array}$ & $\begin{array}{l}18 \text { OECD } \\
\text { countries, } \\
1971-1998\end{array}$ & $\begin{array}{l}\text { Bassanini } \\
\text { and } \\
\text { Scarpatta } \\
(2001)\end{array}$ & $\begin{array}{l}\text { The combined effect of } \\
\text { expansionary discretionary } \\
\text { fiscal policy and automatic } \\
\text { stabilisers is powerful for } \\
\text { accelerating recovery in } \\
\text { industrial countries and non- } \\
\text { Sub-Saharan African } \\
\text { developing countries. }\end{array}$ & $\begin{array}{l}\text { Panel } \\
\text { regressions }\end{array}$ & $\begin{array}{l}197 \\
\text { developed } \\
\text { and } \\
\text { developing } \\
\text { countries, } \\
1960-2005\end{array}$ & $\begin{array}{l}\text { Cerra et al. } \\
(2008)\end{array}$ & & & & \\
\hline & & & & & $\begin{array}{l}\text { The effectiveness of automatic } \\
\text { stabilisers apply with equal } \\
\text { strength to a broad set of highly } \\
\text { heterogeneous countries. }\end{array}$ & $\begin{array}{l}\text { Panel } \\
\text { regressions }\end{array}$ & $\begin{array}{l}49 \text { developed } \\
\text { and } \\
\text { developing } \\
\text { economies, } \\
1970-2006\end{array}$ & $\begin{array}{l}\text { Debrun } \\
\text { and } \\
\text { Kapoor } \\
(2010)\end{array}$ & & & & \\
\hline \multirow[t]{3}{*}{$\begin{array}{l}\text { Discretionary } \\
\text { policies }\end{array}$} & $\begin{array}{l}\text { Exte rnal sector } \\
\text { imbalance s: An } \\
\text { improvement in the } \\
\text { government budget balance to } \\
\text { GDP improves the current } \\
\text { account balance to GDP ratio. }\end{array}$ & $\begin{array}{l}\text { Panel } \\
\text { regressions }\end{array}$ & $\begin{array}{l}19 \\
\text { developed } \\
\text { and } 69 \\
\text { developing } \\
\text { countries, } \\
\text { 1971-2004 }\end{array}$ & $\begin{array}{l}\text { Chinn and } \\
\text { Ito (2008) }\end{array}$ & $\begin{array}{l}\text { Fiscal multipliers associated } \\
\text { with government spending } \\
\text { depend on the business cycle. } \\
\text { They fluctuate from being } \\
\text { statistically insignific ant in } \\
\text { normal times and in expansions } \\
\text { to being significant positive } \\
\text { during recessions. }\end{array}$ & $\begin{array}{l}\text { Regime- } \\
\text { switching } \\
\text { SVAR } \\
\text { models }\end{array}$ & $\begin{array}{l}\text { USA, 1947Q1- } \\
\text { 2008Q4 }\end{array}$ & $\begin{array}{l}\text { Auerbach } \\
\text { and Gorod- } \\
\text { nichenko } \\
(2012)\end{array}$ & $\begin{array}{l}\text { In systemic banking crisis timely } \\
\text { countercyclical fiscal } \\
\text { measures shorten the crisis } \\
\text { with government consumption } \\
\text { being more effective than } \\
\text { public investments and income } \\
\text { tax cuts. Do not hold for } \\
\text { countries with limited fiscal } \\
\text { space preventing fiscal } \\
\text { expansions by funding } \\
\text { constraints. }\end{array}$ & $\begin{array}{l}\text { OLS and } \\
\text { Ordered } \\
\text { Logit } \\
\text { regressions }\end{array}$ & $\begin{array}{l}118 \\
\text { banking } \\
\text { crises in } 99 \\
\text { countries, } \\
\text { 1980-2008 }\end{array}$ & $\begin{array}{l}\text { Baldacci } \\
\text { et al. } \\
\text { (2009) }\end{array}$ \\
\hline & $\begin{array}{l}\text { Financial sector } \\
\text { imba la nce s: Fiscal } \\
\text { tightening in a credit boom is } \\
\text { not associated with a reduced } \\
\text { incidence of credit booms, nor } \\
\text { a lower probability of a boom } \\
\text { ending badly. }\end{array}$ & $\begin{array}{l}\text { Panel } \\
\text { regressions }\end{array}$ & $\begin{array}{l}170 \\
\text { countries, } \\
1960 \text { s- } 2010\end{array}$ & $\begin{array}{l}\text { Dell' } \\
\text { Ariccia et } \\
\text { al. (2013) }\end{array}$ & $\begin{array}{l}\text { Discretionary fiscal policy is in } \\
\text { general more effective on } \\
\text { output under a currency peg } \\
\text { than under a flexible exchange } \\
\text { rate regime and when there is a } \\
\text { financial crisis. High public debt } \\
\text { or deficit make fiscal spending } \\
\text { have no impact on output. }\end{array}$ & $\begin{array}{l}\text { Panel } \\
\text { regressions }\end{array}$ & $\begin{array}{l}17 \text { OECD } \\
\text { countries, } \\
1975-2008\end{array}$ & $\begin{array}{l}\text { Corsetti et } \\
\text { al. (2012) }\end{array}$ & $\begin{array}{l}\text { Frontloaded consolidations } \\
\text { tend to be more contractionary } \\
\text { on GDP relative to smoother } \\
\text { consolidations. "Strong" fiscal } \\
\text { consolidations are more likely } \\
\text { to trigger or extend downturns } \\
\text { than "mild" consolidations. }\end{array}$ & $\begin{array}{l}\text { Threshold } \\
\text { vector- } \\
\text { autoregres- } \\
\text { sive (TVAR) } \\
\text { model }\end{array}$ & $\begin{array}{l}5 \\
\text { countries, } \\
\text { 1970Q1- } \\
2010 Q 2\end{array}$ & $\begin{array}{l}\text { Batini et } \\
\text { al. (2012) }\end{array}$ \\
\hline & & & & & $\begin{array}{l}\text { Fiscal stimulus is particularly } \\
\text { helpful during recessions } \\
\text { associated with financial crises. }\end{array}$ & $\begin{array}{l}\text { Duration } \\
\text { analysis }\end{array}$ & $\begin{array}{l}21 \text { OECD } \\
\text { countries, } \\
1960-2007\end{array}$ & $\begin{array}{l}\text { Kannan et } \\
\text { al. (2009) }\end{array}$ & $\begin{array}{l}\text { Increases in government } \\
\text { consumption strengthen the } \\
\text { recovery. }\end{array}$ & $\begin{array}{l}\text { Duration } \\
\text { analysis }\end{array}$ & $\begin{array}{l}21 \text { OECD } \\
\text { countries, } \\
\text { 1960-2007 }\end{array}$ & $\begin{array}{l}\text { Kannan et } \\
\text { al. (2009) }\end{array}$ \\
\hline $\begin{array}{l}\text { Public } \\
\text { spending }\end{array}$ & $\begin{array}{l}\text { Exte rnal se c tor } \\
\text { imba lanc es : Higher social } \\
\text { spending (in particular on } \\
\text { health care) reduces the } \\
\text { saving rate (lower } \\
\text { precautionary savings) which } \\
\text { weakens the current account. }\end{array}$ & $\begin{array}{l}\text { Time- series } \\
\text { regressions } \\
\text { within an } \\
\text { error } \\
\text { correction } \\
\text { framework }\end{array}$ & $\begin{array}{l}30 \text { OECD } \\
\text { countries, } \\
1965-2008\end{array}$ & $\begin{array}{l}\text { Kerdrain } \\
\text { et al. } \\
\text { (2010) }\end{array}$ & & & & & & & & \\
\hline
\end{tabular}

Note: All the mentioned effects are statistically signific ant if not otherwise mentioned. The grey- shaded boxes indic ate OECD-work. 


\section{Financial market policies}

\section{Financial market policies to reduce vulnerabilities}

24. Vulnerabilities in the financial sector mainly arise for two reasons: i) underpricing of (measured) risk in boom times can lead to excessive leverage, and maturity and currency mismatches; and ii) the interconnectedness and common exposures of the financial sector can make individual institutions systemically important. Vulnerabilities in the financial sector can spill over to other sectors via credit and asset price booms, capital inflow surges and risks of potential bailouts as described in detail in Roehn et al. (2015). Hence, effective policies to address financial market vulnerabilities have potentially large benefits.

25. Macro-prudential measures are aimed at leaning against systemic threats to financial stability arising for example from excessive credit, leverage and asset price growth. While monetary policy could in principle act to influence these systemic threats via interest and credit channels, it is a blunt tool and potential economic costs of misinterpreting vulnerabilities and mistiming interventions are likely higher compared to more targeted macro-prudential tools. The macro-prudential tool box is vast. For example, to counter excessive credit growth and leverage several measures can be applied: countercyclical capital buffers, dynamic provisioning, caps on loan-to-value (LTV) and debt-to-income (DTI) ratios, and increasing risk weights on particular asset exposures. To address increasing maturity mismatch and liquidity risk the following can be used: time-varying liquidity buffers and haircut or margin requirements as well as limits to loan-to-deposit ratios.

26. Experience with macro-prudential tools is still limited and mostly confined to emerging economies, but some evidence on their beneficial effects has started to emerge. For example, limits on DTI and LTV ratios are associated with lower credit growth (IMF, 2012) and higher LTV ratios are found to slow house price inflation and contain feedbacks between assets prices and credit (e.g. Claessens, 2014; Crowe et al., 2013). Conditional on a housing bust, the presence of a LTV cap is found to limit the vulnerability of banking systems to mortgage default (Hong Kong Monetary Authority, 2011). In addition, Claessens et al. (2013) show that caps on DTI and LTV ratios and limits on credit growth and foreign currency lending are effective in reducing leverage, asset and non-core to core liabilities growth during boom times. Countercyclical buffers (such as reserve requirements, limits on profit distribution, and dynamic provisioning) also help mitigate increases in bank leverage and assets. ${ }^{2}$

27. Despite this encouraging evidence about their effectiveness, macro-prudential tools face implementation challenges in practice. Given that macro-prudential policy is primarily aimed at containing systemic risk, it has to be employed pre-emptively before system-wide threats develop. Choosing the right timing to introduce a measure can prove to be difficult and implementation may be resisted by interest groups. Moreover, little is known about how various macro-prudential tools interact and about their interaction with micro-prudential tools, monetary and fiscal policies. International spill-overs may also affect the effectiveness of the tools (Claessens, 2014). Hence, calibrating various instruments so as to take into account their expected costs and benefits as well as interactions with other measures and policies is not straightforward. Another issue is whether measures should be rule-based, or whether discretion should be allowed.

28. Systemically important financial institutions raise particular regulatory challenges. As the size or interconnectedness of these institutions makes them too-big-to-fail (TBTF), they benefit from implicit and explicit public guarantees. This gives rise to moral hazard leading to overly risky lending and adverse feedback loops between sovereigns and banks. Besides threatening financial stability, implicit and explicit subsidies are likely to generate rents and distortions that reduce growth. These rents can be sizeable. For

2. Claessens (2014), OECD (2013a), and Lim et al. (2011) provide examples of country specific experiences with macro-prudential tools. 
example, Schich et al. (2014) estimate that public backing reduced the funding costs of a sample of large European banks by 1.3 percentage points in 2013.

29. To reduce de facto public support to systemically important financial institutions, too-big-to-fail (TBTF) banks' higher-risk activities could be separated from their systemic utility functions (BlundellWignall and Atkinson, 2012) ( $^{3}$ or TBTF banks could be to split into entities sufficiently small that they could go bankrupt without creating systemic risk (Cournède and Denk, 2014a). Second-best regulatory remedies include in particular capital surcharges for TBTF banks, requirements for credible resolution plans (so-called "living wills"), and a wider participation of the private sector in the sharing of losses of insolvent banks. Many OECD countries are currently pursuing reforms along these lines at the national and international level in particular under the auspices of the European Union and the Basel Committee for Banking Supervision (BCBS).

30. Incentive problems in financial sector remuneration systems may lead to excessive risk taking in good times. These problems could be tackled, for instance, by restricting pay that encourages short-sighted risk-taking, such as performance bonuses without claw-back provisions. Recent OECD work (Cournède and Denk, 2014b) further argues that substantial wage premia in the financial sector can hurt growth through misallocation of talent and greater income inequality. Reforms to improve compensation practices in the financial sector are, therefore, unlikely to hurt growth.

31. Risk illusion, i.e. the collective underestimation of risk due to short-term memory and the infrequency of financial crises can be counteracted through limit values on high-risk banking activities. As an example the Basel Committee on Banking Supervision suggests measuring and controlling large exposures with a limit value for large exposures set at 25\% of a bank's tier 1 capital (BIS, 2014). Nonetheless, limit values must balance the trade-off between limiting risk taking and allowing banks to carry out profitable banking activities and extend credit.

\section{Financial market policies: shock mitigation and recovery}

32. The financial sector often propagates shocks and crises involving the impairment of financial intermediation frequently leading to large economic costs. Hence, prudential tools aim at increasing the shock absorption capacity of the financial sector.

33. Strong capital and liquidity buffers as well as sufficient loan loss provisioning are important ingredients to increase the shock absorption capacity of the financial sector. Large capital buffers reduce the extent to which financial firms can build-up leverage in boom times and increase the distance to default in case of an adverse shock. Furthermore, the global financial crisis has shown that market liquidity can evaporate quickly in the face of a shock. Maintaining a large share of high quality and highly liquid assets is thus important to reduce the risk that financial firms are forced to fire-sell illiquid assets with potential spill-over effects to other financial firms and that liquidity problems turn into solvency problems. The Basel III framework acknowledges the need for higher buffers especially by requiring that banks hold an adequate stock of unencumbered liquid assets and finance at least 3\% of their total assets (including offbalance sheet exposures) with equity. However, the OECD has advocated a more prudent leverage ratio of 5\% (Blundell-Wignall and Atkinson, 2012; OECD, 2014b). In addition, Blundell-Wignall and Roulet (2013) provide evidence that parts of the Basel III framework that pertain to capital ratios based on risk-weighted assets are less effective at curbing bank credit risk than the leverage ratio.

3. In particular, if the gross market value of derivatives reaches $10 \%$ of a banks' portfolio, based on IFRS accounting, then high-risk activities, including prime broking, market-making, underwriting and most derivatives activities be separated into a ring-fenced subsidiary within a Non-Operating Holding Company (NOHC) structure (OECD, 2014a). Large portfolios of derivatives expose banks to high levels of market risk and hence increase banks' risk of insolvency. 
Table 3. Empirical evidence on the linkages between financial market policies and resilience

\begin{tabular}{|c|c|c|c|c|c|c|c|c|c|c|c|}
\hline \multirow[b]{2}{*}{ Policy } & \multicolumn{4}{|c|}{ VuIne rability } & \multicolumn{4}{|c|}{ Resistance } & \multicolumn{3}{|c|}{ Recovery } \\
\hline & Results & Method & Sample & Study & Results & Method & Sample & Study & Results & Method Sample & Study \\
\hline \multirow[t]{4}{*}{$\begin{array}{l}\text { Macro- } \\
\text { prudential } \\
\text { measures }\end{array}$} & $\begin{array}{l}\text { Financial and non-financial sector } \\
\text { imba la nce s: Limits on DTI and LTV } \\
\text { ratios, credit growth and foreign currency } \\
\text { lending are effective in reducing leverage, } \\
\text { asset and noncore to core liabilities } \\
\text { growth in boom times. Countercyclical } \\
\text { buffers (e.g. reserve requirements and } \\
\text { dynamic provisioning) help mitigate } \\
\text { increases in bank leverage and assets. }\end{array}$ & $\begin{array}{l}\text { GMM panel } \\
\text { data } \\
\text { regressions }\end{array}$ & $\begin{array}{l}48 \\
\text { countries, } \\
2000-10\end{array}$ & $\begin{array}{l}\text { Claessens } \\
\text { et al. (2013) }\end{array}$ & $\begin{array}{l}\text { Macro-prudential policies are overall } \\
\text { ineffective in restorating financial } \\
\text { intermediation during adverse } \\
\text { conditions. However, a group of } \\
\text { policies directed banks (e.g. } \\
\text { countercyclical provisioning and } \\
\text { capital requirements) helps maintain } \\
\text { growth in asset prices. }\end{array}$ & $\begin{array}{l}\text { GMM panel } \\
\text { data } \\
\text { regressions }\end{array}$ & $\begin{array}{l}48 \\
\text { countries, } \\
2000-10\end{array}$ & $\begin{array}{l}\text { Claessens } \\
\text { et al. (2013) }\end{array}$ & & & \\
\hline & $\begin{array}{l}\text { Non- financial and external sector } \\
\text { imba lances: Requirements on capital } \\
\text { and reserves reduce credit growth. Capital } \\
\text { requirements and limits on LTV ratios } \\
\text { reduce house price appreciation. In } \\
\text { emerging economies increases in reserve } \\
\text { requirements limit portfolio inflows. }\end{array}$ & $\begin{array}{l}\text { Panel } \\
\text { regressions }\end{array}$ & $\begin{array}{l}36 \\
\text { countries, } \\
2000-11\end{array}$ & $\operatorname{IMF}(2013)$ & & & & & & & \\
\hline & $\begin{array}{l}\text { Financial sector imba lances: Limits } \\
\text { on LTV ratios reduce the vulnerability of } \\
\text { banking systems to property price shocks. }\end{array}$ & $\begin{array}{l}\text { Panel } \\
\text { regressions }\end{array}$ & $\begin{array}{l}13 \text { countries, } \\
1991 \mathrm{1}- \\
2010 \mathrm{Q} 2\end{array}$ & $\begin{array}{l}\text { Hong Kong } \\
\text { Monetary } \\
\text { Authority } \\
\text { (2011) }\end{array}$ & & & & & & & \\
\hline & $\begin{array}{l}\text { Non- financial and financial sector } \\
\text { imba la nces: Macroprudential tools can } \\
\text { reduce the incidence of credit booms and } \\
\text { decrease the probability that booms end } \\
\text { up badly. }\end{array}$ & $\begin{array}{l}\text { Panel } \\
\text { regressions }\end{array}$ & $\begin{array}{l}170 \\
\text { countries, } \\
1960 \text { s-2010 }\end{array}$ & $\begin{array}{l}\text { Dell'Ariccia } \\
\text { et al. (2013) }\end{array}$ & & & & & & & \\
\hline $\begin{array}{l}\text { Banking } \\
\text { supervision }\end{array}$ & $\begin{array}{l}\text { Asset market imba la nces: Rigorous } \\
\text { banking supervision has been associated } \\
\text { with lower real house price volatility. }\end{array}$ & $\begin{array}{l}\text { Panel } \\
\text { regressions }\end{array}$ & $\begin{array}{l}20 \text { OECD } \\
\text { countries, } \\
\text { ca. } 1980- \\
2005\end{array}$ & $\begin{array}{l}\text { Andrews et } \\
\text { al. (2011) }\end{array}$ & & & & & & & \\
\hline
\end{tabular}


Table 3. Empirical evidence on the linkages between financial market policies and resilience (cont.)

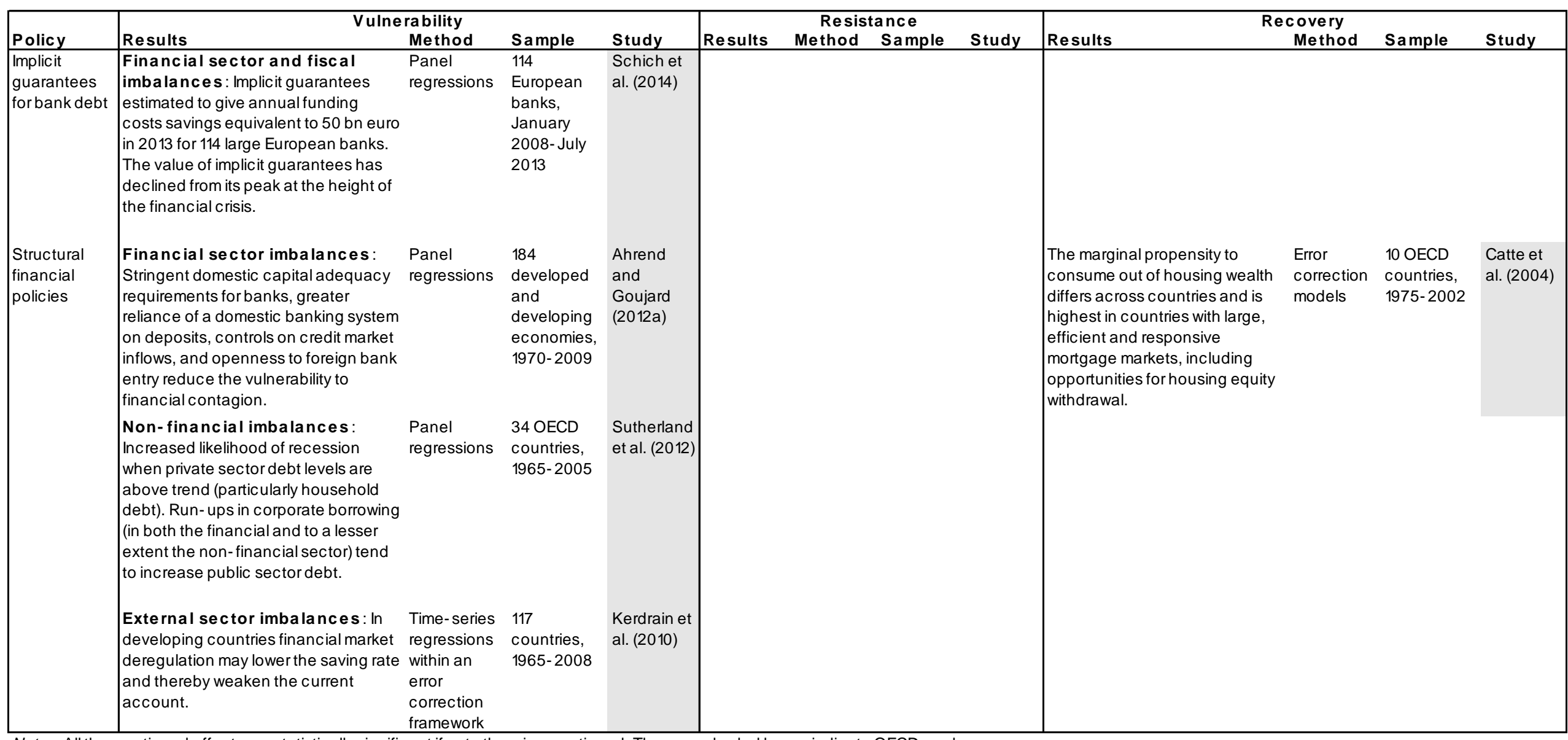

Note: All the mentioned effects are statistically signific ant if not otherwise mentioned. The grey-shaded boxes indic ate OECD- work. 


\section{Tax policy}

\section{Tax distortions contribute to vulnerabilities}

34. The global financial crisis has spurred a debate on whether a number of tax distortions may have contributed indirectly to the crisis by encouraging excessive leverage and other financial market problems (e.g. IMF, 2009; Hemmelgarn and Nicodème, 2010). Three types of distortions are often singled out: a bias towards corporate debt in many tax systems, a favourable tax treatment of housing, and tax preferences for executive compensation packages.

Bias towards corporate debt

35. Corporate tax systems generally encourage debt rather than equity finance in many economies (Figure 2) contributing to creating vulnerabilities in the financial, non-financial and external sectors. The basic mechanism is as follows. Because in most countries interest payments are deductible from the corporate income tax base, while returns on equity (such as dividends paid to shareholders or capital gains on shares) are not, corporate taxes typically create a bias towards debt financing among companies. High levels of leverage can make (financial and non-financial) companies more vulnerable to economic shocks and increase the probability of bankruptcy. Debt financing also provides strong incentives for corporations to increase their risk profile enhancing the possibility of boom and bust periods. OECD work (Ahrend and Goujard, 2012a) has also found that corporate tax systems favouring debt over equity are associated with a higher share of debt in external financing, which contributed to increase the risks of financial crises.

Figure 2. Debt bias of corporate finance in OECD countries

Percentage point difference between the effective tax rates on equity finance and debt finance, 2011

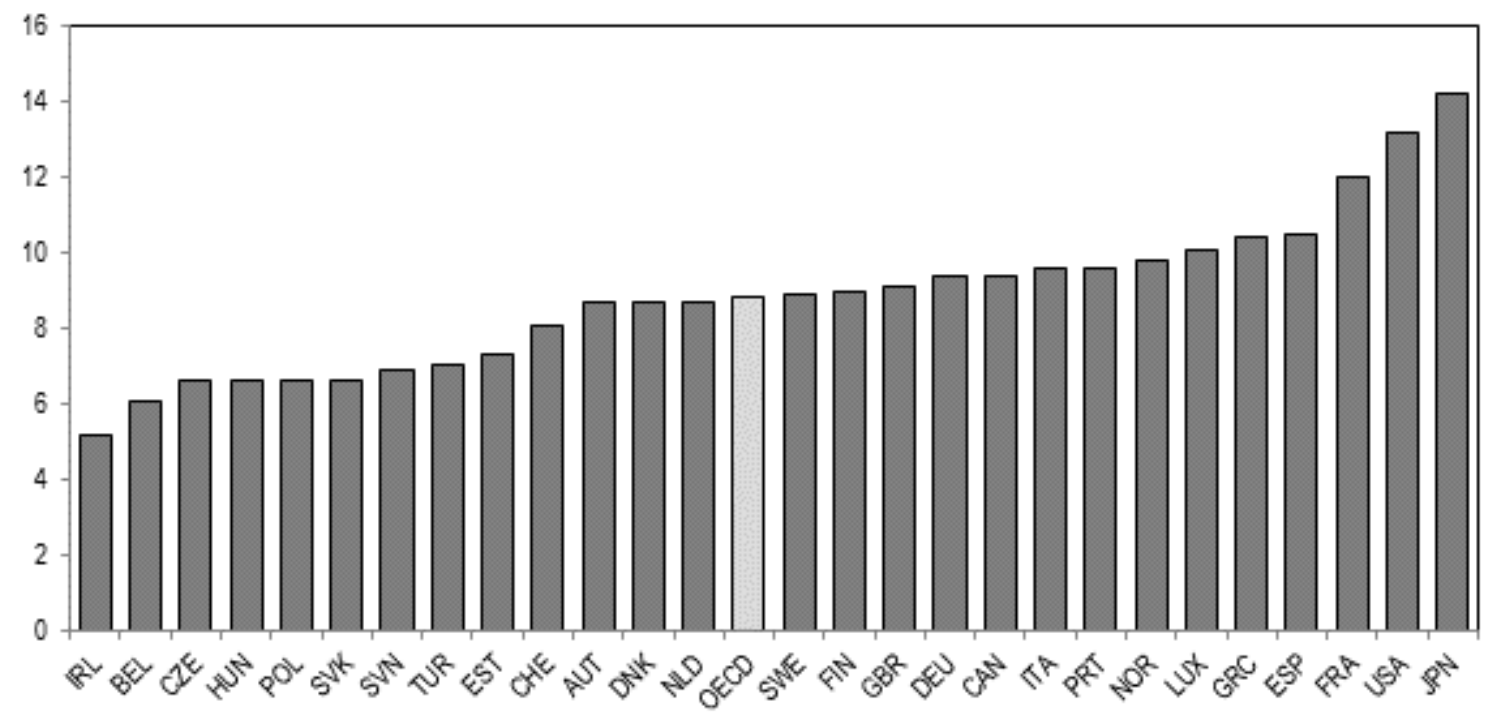

Source: Cournède and Denk (2014b).

Favourable tax treatment of housing

36. Housing is subject to a favourable tax treatment in many countries. Homeowners benefit from tax advantages, compared to other assets. Under a neutral tax treatment, imputed rents and capital gains would be fully taxed and mortgage interest payments would be fully deductible. However, imputed rents and capital gains are seldom taxed (Andrews et al. 2011). On the other hand, a common tax advantage is 
mortgage interest tax relief, whereby mortgage interests related to the main residence are often deductible from personal income tax. This generates a bias towards ownership versus renting leading to higher prices and higher debt relative to a neutral tax treatment. For instance, van den Noord (2005) shows that a tax system that subsidises homeownership tends to increase house price volatility. OECD work by Andrews et al. (2011) suggests that in countries having more generous housing tax relief on debt financing costs, a positive demand shock translates into an increase in house prices that is around 50\% larger than in the typical OECD country.

Tax preferences for executive compensation

37. Tax policy may distort the level and form of executive compensation. An important part of executive compensation packages comes in the form of performance-related pay (e.g. bonuses, stock options). To the extent that performance-related pay benefits from tax preferences in several OECD countries (OECD, 2012), tax policy may affect the balance between salary and performance-pay in executive compensation packages. As performance-related pay generally increases in value with the riskiness of the actions executives take, at least for stock options, this can lead to higher risk taking.

\section{Tax policy: shock mitigation and recovery}

38. Tax systems favouring debt do not only create vulnerabilities but also shape the response of the economy following a shock. A large empirical literature has found that more debt-intensive economic expansions tend to be followed by deeper recessions and slower recoveries (e.g. Dell'Ariccia et al., 2012; Jordà et al., 2013; Sutherland and Hoeller, 2012). As debt represents a non-state contingent liability, debtservice payments are independent of the state of the economy. At high levels of debt, a negative income or revenue shock can squeeze cash flows and force households and firms to cut back on consumption and investment. Similarly, at higher levels of debt, asset price shocks (such as declines in house prices) will have more strongly reduced net wealth. Lower net wealth will translate into lower private spending and also reduce access to borrowing, forcing households and firms to deleverage (see Roehn et al. 2015 for a discussion). If debt and capital overhangs are sizeable, this deleveraging process may depress economic activity for protracted periods. 
ECO/WKP(2015)69

Table 4. Empirical evidence on the linkages between tax policy and resilience

\begin{tabular}{|c|c|c|c|c|c|c|c|c|c|c|c|c|}
\hline \multirow[b]{2}{*}{ Policy } & \multicolumn{4}{|c|}{ Vulnerability } & \multicolumn{4}{|c|}{ Resistance } & \multicolumn{4}{|c|}{ Recovery } \\
\hline & Results & Method & Sample & Study & Results & Method & Sample & Study & Results & Method & Sample & Study \\
\hline $\begin{array}{l}\text { Taxation of } \\
\text { corporate } \\
\text { debt }\end{array}$ & $\begin{array}{l}\text { Non-financial imbalances: A } \\
\text { rise in the corporate tax } \\
\text { income rate increases the } \\
\text { share of debt in external } \\
\text { liabilities, and reduces } \\
\text { reliance on external equity } \\
\text { finance. }\end{array}$ & $\begin{array}{l}\text { Panel } \\
\text { regressions }\end{array}$ & $\begin{array}{l}184 \\
\text { developed } \\
\text { and } \\
\text { developing } \\
\text { economies, } \\
1970 \text { to } \\
2009\end{array}$ & $\begin{array}{l}\text { Ahrend and } \\
\text { Goujard } \\
\text { (2012a) }\end{array}$ & & & & & $\begin{array}{l}\text { The aftermath of leveraged } \\
\text { booms is associated with } \\
\text { slower output and credit } \\
\text { growth and less investment } \\
\text { spending than in other } \\
\text { recessions. }\end{array}$ & $\begin{array}{l}\text { Panel } \\
\text { regressions }\end{array}$ & $\begin{array}{l}14 \text { developed } \\
\text { countries, } \\
1870-2008\end{array}$ & $\begin{array}{l}\text { Jordà et } \\
\text { al. (2013) }\end{array}$ \\
\hline \begin{tabular}{|l} 
Tax \\
treatment \\
of housing
\end{tabular} & $\begin{array}{l}\text { Asset market imbalances: In } \\
\text { countries with more generous } \\
\text { housing tax relief on debt } \\
\text { financing costs a positive } \\
\text { demand shock increases } \\
\text { house prices by around } 50 \% \\
\text { more than in the typical } \\
\text { OECD country. }\end{array}$ & $\begin{array}{l}\text { Panel } \\
\text { regressions }\end{array}$ & $\begin{array}{l}19 \text { OECD } \\
\text { countries, } \\
\text { ca. } 1980- \\
2005\end{array}$ & $\begin{array}{l}\text { Andrews et } \\
\text { al. (2011) }\end{array}$ & $\begin{array}{l}\text { A generous tax relief on } \\
\text { debt financing cost appears } \\
\text { to amplify house price } \\
\text { volatility. }\end{array}$ & $\begin{array}{l}\text { Panel } \\
\text { regressions }\end{array}$ & $\begin{array}{l}20 \text { OECD } \\
\text { countries, } \\
\text { ca. } 1980- \\
2005\end{array}$ & $\begin{array}{l}\text { Andrews et } \\
\text { al. (2011) }\end{array}$ & $\begin{array}{l}\text { Variations in housing market } \\
\text { wealth have important effects } \\
\text { upon consumption implying } \\
\text { that a house price bust } \\
\text { reduces consumption. }\end{array}$ & $\begin{array}{l}\text { Panel } \\
\text { regressions }\end{array}$ & $\begin{array}{l}2 \text { datasets: i) } \\
14 \text { developed } \\
\text { countries, } \\
\text { various years } \\
\text { from } 1975 \text { to } \\
1999 ; \text { ii) US } \\
\text { states, 1982- } \\
2009\end{array}$ & $\begin{array}{l}\text { Case and } \\
\text { Quigley } \\
\text { (2005) }\end{array}$ \\
\hline & $\begin{array}{l}\text { Asset market imbalances: } \\
\text { Higher rates of property } \\
\text { taxation can help limit housing } \\
\text { booms as well as short-run } \\
\text { volatility around an upward } \\
\text { trend in prices. }\end{array}$ & $\begin{array}{l}\text { Instrument } \\
\text { variable } \\
\text { regressions }\end{array}$ & $\begin{array}{l}243 \text { U.S. } \\
\text { metropolitan } \\
\text { statistical } \\
\text { areas, 1998- } \\
2007\end{array}$ & $\begin{array}{l}\text { Crowe et } \\
\text { al. (2013) }\end{array}$ & & & & & & & & \\
\hline
\end{tabular}

Note: All the mentioned effects are statistically significant if not otherwise mentioned. The grey-shaded boxes indicate OECD-work. 


\section{Labour market policies and institutions}

39. Labour market policies and institutions play a role in shaping the way the labour market reacts to shocks in at least two ways (Blanchard, 1999). First, labour market institutions and policies can cushion the impact of shocks, through their effects on earnings and employment. Second, labour market institutions can affect the extent to which higher unemployment persists following an initial cyclical increase.

- Unemployment insurance: Generous unemployment benefits, in particular high replacements rates, can mitigate the decline in individual income following adverse macroeconomic shocks. At the same time, high and (particularly) long lasting unemployment benefits can have adverse employment effects and slow the recovery by weakening job-search intensity and lengthening unemployment spells and persistency. At the macro level, there is indeed evidence that generous unemployment benefits increase the persistence of unemployment following an economic downturn (OECD, 2012). Bassanini (2012) further finds that generous unemployment benefits amplify the negative effects of macroeconomic shocks on total labour earnings. Generous benefits would lead to higher unemployment spells putting pressure on employment and wages and negatively impacting earnings.

- Employment protection legislation (EPL): Employment protection can mitigate the impact of adverse shocks on labour income and jobs during downturns by inducing labour hoarding. But overly stringent dismissals regulation can also slow the recovery from adverse shocks by hampering labour reallocation (Bassanini and Duval, 2007). Furthermore, to the extent that employment protection shelters insiders against the risk of a job loss, they can also resist pressures to reduce wages slowing the wage adjustments and possibly the recovery in the face of adverse shocks (Bertola, 1999). The evidence on the role of employment protection legislation on mitigating the impact of shocks and slowing the recovery is mixed. OECD work by Duval et al. (2007) preceding the crisis suggested that tight job protection cushions the impact of a shock on the output gap, but gives rise to greater persistence (takes longer for the output gap to close). On the other hand, recent evidence by Sutherland and Hoeller (2013) including the crisis period suggests that tight employment protection for regular workers does not mitigate the impact of shocks on the output gap, while it still gives rise to greater persistency.

- Wage setting institutions: Co-ordinated or highly centralised wage-bargaining institutions can mitigate the direct impact of negative output shocks on employment by increasing the responsiveness of real wages and/or working hours to changes in macroeconomic conditions (Blanchard, 1999; Bassanini and Duval, 2006). However, if shocks are heterogeneous across the economy and persistent, adjustment may become more difficult relative to a more decentralised system slowing the adjustment and thus the recovery.

- Active labour market policies (ALMPs): Effective ALMPs can be expected to speed the recovery in the aftermath of an adverse shock by speeding up the re-employment of job losers and improving job matching. The quality of ALMPs is, of course, important and different job-seekers need different types of ALMPs (OECD, 2013b).

- Minimum wages: Minimum wages can prevent nominal wages at the lower end of the distribution from bearing the brunt of adjustment to a shock (OECD, 2014c). Yet a high statutory minimum wage can slow wage adjustments in the aftermath of an adverse aggregate shock and slow the recovery. The evidence is, however, inconclusive in this respect. Bassanini (2012) finds that high minimum wages mitigate the impact of macroeconomic shocks on the cyclicality of wages; however, he finds no effect on total earnings and no effect on the persistency of shocks. On the other hand, Ahrend et al. (2011) find that high and, especially, far reaching statutory minimum 
wages have had adverse impacts on youth employment and youth unemployment in the wake of numerous macroeconomic shocks.

- Short-time work schemes (STW): Short-time work schemes are public schemes intended to preserve jobs at firms experiencing temporarily low demand by encouraging work-sharing. STW schemes can mitigate the impact of shocks on workers by providing income-support to workers whose hours are reduced and by reducing the inflow of workers into unemployment. On the other hand, if not well-designed they can impede structural change and slow the recovery, especially in the face of a permanent adverse supply shock. Indeed, Hijzen and Martin (2013) find that STW schemes have helped preserve a significant number of jobs during the Great Recession, but its continued use during the recovery slowed the job-content of the recovery. A way to ensure that STW schemes enhance resilience is to shorten their duration and limit their use to downturns.

- Retirement, long-term sickness and disability schemes: During downturns when unemployment rises there is strong temptation to facilitate early retirement for older employees and ease access to long-term sickness or disability schemes for employees with health problems in an effort to mitigate the income and unemployment impacts of adverse shocks. Yet these schemes have proved to be particularly damaging in the past. They have undermined long-run labour supply leading to lower potential growth and have permanently increased social expenditures in many countries (OECD, 2009b). In the current crisis, there has not been a massive inflow of unemployed people into early retirement or disability schemes thanks to pre-crisis structural reforms, particularly to disability schemes (i.e. strengthened gate keeping, assessment of health conditions, and incentives to return to work) (OECD, 2014c).

40. Indirectly, labour market institutions can affect the impact of shocks through their effect on wage stickiness or rigidities. In the face of negative shocks, employment adjustment is likely to be larger when wages are rigid downwards, which is often the case, at least for the nominal wages of incumbents (Bassanini, 2012). Labour market institutions - notably wage bargaining and employment protection legislation - are typically considered to explain cross-country differences in wage rigidity patterns (Bertola and Rogerson, 1997; Babecký et al., 2009). For instance, Babecký et al. (2009) find that, in Europe, downward nominal rigidity is stronger in countries with stricter employment protection regulations and a higher degree of collective bargaining coverage.

41. Finally, labour market institutions also influence the recovery from shocks by shaping the pace of job and residential mobility. Low job and residential mobility hamper reallocation and thus reduce the speed of adjustment and recovery from shocks (Blanchard and Katz, 1992). Institutions, such as stringent labour protection, high unemployment benefits, wage co-ordination or weak active labour market policies, are associated with lower labour mobility and employment rates (e.g. Bassanini and Duval (2006) and Blanchard and Wolfers (2000)). Labour market institutions may also play a role on the pace of regional mobility. For instance, evidence suggests that intra-country migration indeed increases following temporary regional shocks in the United States, but not in Europe where unemployment insurance schemes are more comprehensive (Blanchard and Katz, 1992; Decressin and Fatás, 1995).

\section{Targeted employment and social policies to mitigate the impact of shocks on vulnerable workers}

42. Severe downturns increase the risks of the unemployed loosing skills and getting discouraged. This risks turning a cyclical increase in unemployment into a permanent increase leading to hysteresis. Some groups of workers, including the low-skilled, the long-term unemployed and the young are more prone to such negative effects and typically need more targeted interventions during a downturn when demand and employment prospects are depressed (OECD, 2009b; 2013b; 2014d). 
- Low-skilled workers: low-paid workers and their families are likely to suffer more than other groups when wages and/or hours worked fall substantially during a severe downturn. In-work benefit schemes for low-paid workers can help strengthen their labour market attachment and reduce the incidence and severity of in-work poverty. Other options include part-time or partial unemployment benefits for those facing involuntary working-hour reductions.

- Long-term unemployed: long-term unemployment can increase substantially after a severe downturn. Well-targeted benefits (e.g. cash benefits, minimum income benefits) can help avert steep rises in poverty and inequality by providing a fall-back option for people no longer receiving unemployment compensation. However, low take-up of such benefits is a common problem in many OECD countries (OECD, 2009b). Take-up can be improved by clearly defining who is legally entitled to assistance, effective information campaigns, one-stop-shops and measures to ensure claimant anonymity.

- Youth: the young are strongly affected by economic downturns and it is particularly important to ensure that they do not loose connection with the labour market or experience permanent reductions in their earnings as a result (OECD, 2013c). Temporarily relaxing eligibility requirements for unemployment benefits and targeted ALMPs for young job losers may help if accompanied by requirements to search for jobs. Measures targeted on at-risk youth about to enter the labour market can also help to minimise the risk of youth entering the labour market without any qualifications. Subsidies for internships or apprenticeship programmes may be helpful in this respect. 
ECO/WKP(2015)69

Table 5. Empirical evidence on the linkages between labour market policies and resilience

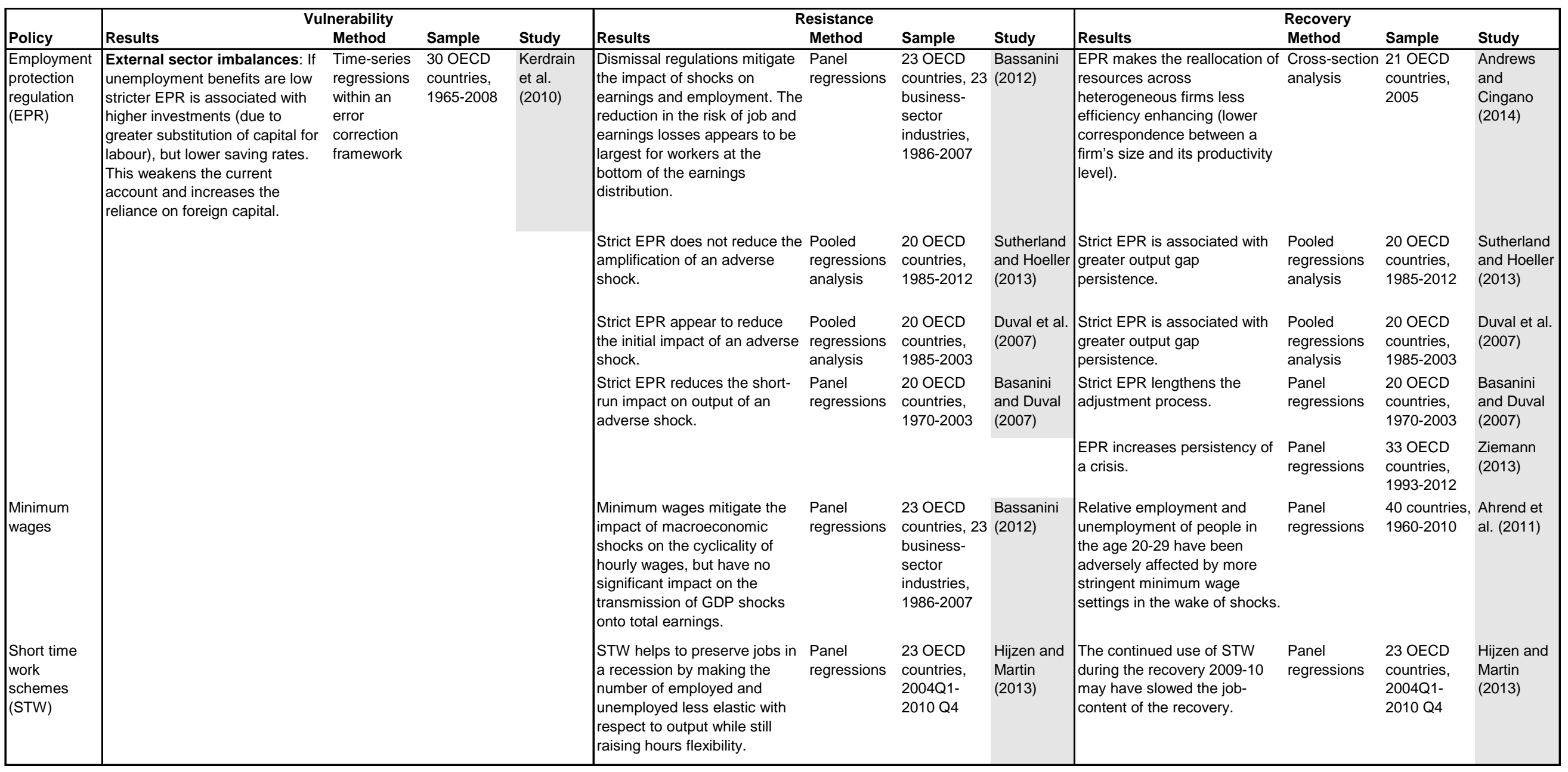


Table 5. Empirical evidence on the linkages between labour market policies and resilience (cont.)

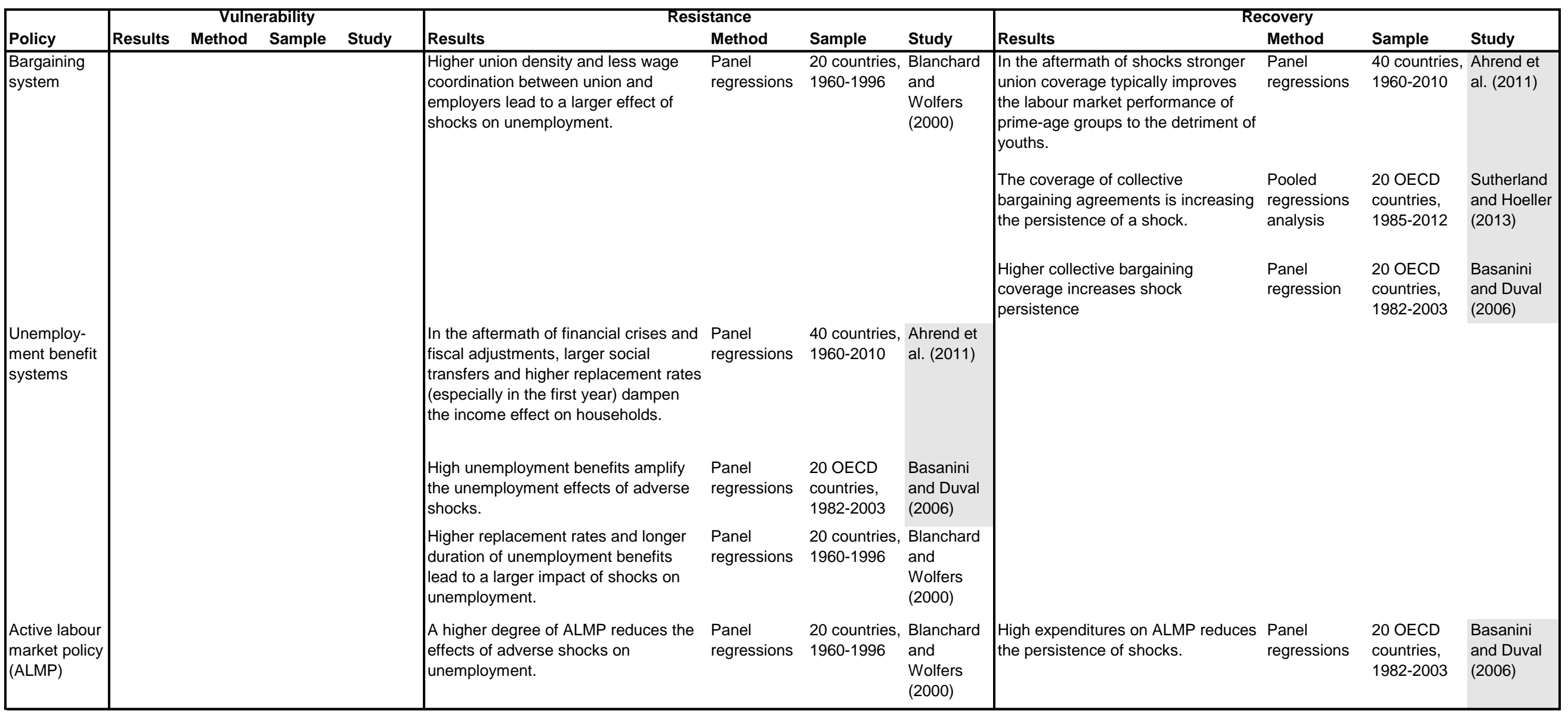

Note: All the mentioned effects are statistically significant if not otherwise mentioned. The grey-shaded boxes indicate OECD-work. 


\section{Product market regulations}

43. Recent OECD evidence suggests that pro-competitive product market regulations strengthen resilience by lowering the impact and reducing the persistence of shocks. For instance, Sutherland and Hoeller (2013) find that lower state control is correlated with lower amplification and persistence of shocks on output gaps. Persistence and to a lesser extent amplification of shocks is also less pronounced in economies with less regulated network industries. Analysis by Ziemann (2013), further suggests that fewer barriers to entrepreneurship are associated with lower macroeconomic volatility and smaller output falls during downturns.

44. Disentangling the exact channel through which pro-competitive product market regulations enhance resilience is, however, not obvious. Several channels can be distinguished:

- Price and wage flexibility channel: Product market reforms that increase competition among firms can also improve the adjustment capacity to adverse macroeconomic shocks by promoting nominal price and wage flexibility, through for instance reducing the oligopolistic behaviour of firms and disciplining mark-ups (Canova et al., 2012). For instance, Geroski (1992) shows that price responses to both supply and demand shocks are faster in more competitive industries. Álvarez and Hernando (2006) further show that product market regulations that restrict competition reduce price flexibility and that in more competitive markets firms adjust prices faster in response to demand and supply shocks. Higher competition then leads to a more rapid adjustment in prices, which would underpin household disposable income and give monetary policy more leeway to respond in a downturn. Furthermore, more flexible product markets will tend to improve the functioning of the labour market through speeding the pace of adjustment (Bassanini and Duval, 2006).

- Reallocation channel: By facilitating entry and exit, pro-competitive product market regulations may smoothen the impact and speed up the recovery from shocks by enabling a quicker and more efficient reallocation of resources within and across sectors and firms. Such reallocation can lead to higher productivity and growth, if less productive firms exit the market and more productive firms remain, the so-called "cleansing effect" of recessions (e.g. Caballero and Hammour, 1996). On the other hand, it might be the case that a surge in job destruction is not matched by an increase in job creation, if the crisis reduces the availability of finance for entrepreneurs (Caballero and Hammour, 2005) and the scope for experimentation (Ziebarth, 2012).

- Innovation channel: Finally, pro-competitive product market regulations may also contribute to speed up the recovery by giving firms stronger incentives to innovate when faced by a shock, other things equal. There is indeed some evidence that innovating firms are much less sensitive to cyclical shocks than non-innovating firms, at least in the UK (e.g. Geroski and Machin, 1993). This could be explained by an increased demand for innovative products that offer lower prices and/or respond better to altered demand during a downturn. The role of bankruptcy regimes on mitigating the impact of shocks and speeding the recovery. 
45. Downturns typically lead to liquidity and insolvency problems among businesses, as firms face declining demand, leading to an increase in corporate and bank failures. A wave of defaults can overwhelm the judicial system, exacerbating value-destroying delays (Ghosh et al., 2009). Inefficient bankruptcy systems that excessively punish business failure, through for instance a costly bankruptcy procedure, can hamper the efficient reallocation of resources by raising the likelihood that resources are trapped in inefficient firms (e.g. Andrews and Cingano, 2014). As such inefficient bankruptcy regimes can hamper reallocation and thereby amplify the impact of shocks and slow the recovery. According to (Djankov, 2009) the efficiency of bankruptcy processes in dealing with crises can be improved by i) minimising dependence on the courts; ii) establishing specialise courts; iii) limiting appeals iv) introducing time limits and v) using the internet to post decisions and publicise auctions. 
Table 6. Empirical evidence on the linkages between product market regulations and resilience

ECO/WKP(2015)69

\begin{tabular}{|c|c|c|c|c|c|c|c|c|c|c|c|c|}
\hline \multirow[b]{2}{*}{ Policy } & \multicolumn{4}{|c|}{ Vulnerability } & \multicolumn{4}{|c|}{ Resistance } & \multicolumn{4}{|c|}{ Recovery } \\
\hline & Results & Method & Sample & Study & Results & Method & Sample & Study & Results & Method & Sample & Study \\
\hline \multirow[t]{5}{*}{\begin{tabular}{|l|} 
Regulation \\
on entrepre- \\
neurship, \\
investment \\
and trade
\end{tabular}} & $\begin{array}{l}\text { Non-financial imbalances: Anti- } \\
\text { competitive domestic PMR and } \\
\text { regulatory barriers to FDI and } \\
\text { equity investment result in } \\
\text { increased bias of external } \\
\text { liabilities towards debt, driven by } \\
\text { increases in external debt } \\
\text { liabilities and decreases in equity } \\
\text { and FDI liabilities. }\end{array}$ & $\begin{array}{l}\text { Panel } \\
\text { regressions }\end{array}$ & $\begin{array}{l}184 \\
\text { developed } \\
\text { and } \\
\text { developing } \\
\text { economies, } \\
\text { 1970-2009 }\end{array}$ & $\begin{array}{l}\text { Ahrend } \\
\text { and } \\
\text { Goujard } \\
\text { (2012a) }\end{array}$ & $\begin{array}{l}\text { Innovating firms are less } \\
\text { sensitive to cyclical shocks } \\
\text { than non-innovating firms. }\end{array}$ & $\begin{array}{l}\text { Panel } \\
\text { regressions }\end{array}$ & $\begin{array}{l}\text { UK, } 539 \text { firms, } \\
1945-83\end{array}$ & $\begin{array}{l}\text { Geroski } \\
\text { and Machin } \\
\text { (1993) }\end{array}$ & $\begin{array}{l}\text { Countries with high barriers } \\
\text { (entry and exit) in the product } \\
\text { market have lower } \\
\text { covariance between firm size } \\
\text { and their productivity (i.e. } \\
\text { lower allocative efficiency). }\end{array}$ & $\begin{array}{l}\text { Cross- } \\
\text { section } \\
\text { analysis }\end{array}$ & $\begin{array}{l}21 \text { OECD } \\
\text { countries, } \\
2005\end{array}$ & $\begin{array}{l}\text { Andrews } \\
\text { and } \\
\text { Cingano } \\
(2014)\end{array}$ \\
\hline & $\begin{array}{l}\text { External sector imbalances: } \\
\text { PMR liberalisation temporarily } \\
\text { boosts investment which } \\
\text { temporarily weakens the current } \\
\text { account. }\end{array}$ & $\begin{array}{l}\text { Time-series } \\
\text { regressions } \\
\text { within an } \\
\text { error } \\
\text { correction } \\
\text { framework }\end{array}$ & $\begin{array}{l}30 \text { OECD } \\
\text { countries, } \\
1965-2008\end{array}$ & $\begin{array}{l}\text { Kerdrain } \\
\text { et al. } \\
\text { (2010) }\end{array}$ & $\begin{array}{l}\text { Low barriers to } \\
\text { entrepreneurship are } \\
\text { associated with reduced real } \\
\text { GDP volatility and } \\
\text { amplitudes. }\end{array}$ & $\begin{array}{l}\text { Panel } \\
\text { regressions }\end{array}$ & $\begin{array}{l}33 \text { OECD } \\
\text { countries, } \\
1993-2012\end{array}$ & $\begin{array}{l}\text { Ziemann } \\
\text { (2013) }\end{array}$ & $\begin{array}{l}\text { PMR generally increases } \\
\text { persistence of a crisis. }\end{array}$ & $\begin{array}{l}\text { Panel } \\
\text { regressions }\end{array}$ & $\begin{array}{l}33 \text { OECD } \\
\text { countries, } \\
1993-2012\end{array}$ & $\begin{array}{l}\text { Ziemann } \\
\text { (2013) }\end{array}$ \\
\hline & & & & & $\begin{array}{l}\text { Lower state control and less } \\
\text { regulated network industries } \\
\text { are correlated with lower } \\
\text { amplification of shocks on }\end{array}$ & $\begin{array}{l}\text { Pooled } \\
\text { regressions } \\
\text { analysis }\end{array}$ & $\begin{array}{l}20 \text { OECD } \\
\text { countries, } \\
1985-2012\end{array}$ & $\begin{array}{l}\text { Sutherland } \\
\text { and Hoeller } \\
\text { (2013) }\end{array}$ & & & & \\
\hline & & & & & $\begin{array}{l}\text { PMR dampen the initial } \\
\text { output gap effect of shocks. }\end{array}$ & $\begin{array}{l}\text { Pooled } \\
\text { regressions } \\
\text { analysis }\end{array}$ & $\begin{array}{l}20 \text { OECD } \\
\text { countries, } \\
1985-2003\end{array}$ & $\begin{array}{l}\text { Duval et al. } \\
\text { (2007) }\end{array}$ & & & & \\
\hline & & & & & $\begin{array}{l}\text { Stringent PMR reduces the } \\
\text { short-run impact of an } \\
\text { adverse shock. }\end{array}$ & $\begin{array}{l}\text { Panel } \\
\text { regressions }\end{array}$ & $\begin{array}{l}20 \text { OECD } \\
\text { countries, } \\
1970-2003\end{array}$ & $\begin{array}{l}\text { Basanini } \\
\text { and Duval } \\
(2007)\end{array}$ & $\begin{array}{l}\text { Stringent PMR lengthens the } \\
\text { adjustment process. }\end{array}$ & $\begin{array}{l}\text { Panel } \\
\text { regressions }\end{array}$ & $\begin{array}{l}20 \text { OECD } \\
\text { countries, } \\
1970-2003\end{array}$ & $\begin{array}{l}\text { Basanini } \\
\text { and Duval } \\
(2007)\end{array}$ \\
\hline $\begin{array}{l}\text { Bankruptcy } \\
\text { system }\end{array}$ & & & & & & & & & $\begin{array}{l}\text { Countries with more stringent } \\
\text { bankruptcy arrangements } \\
\text { have lower covariance } \\
\text { between firm size and their } \\
\text { productivity (i.e. lower } \\
\text { allocative efficiency). }\end{array}$ & $\begin{array}{l}\text { Cross- } \\
\text { section } \\
\text { analysis }\end{array}$ & $\begin{array}{l}21 \text { OECD } \\
\text { countries, } \\
2005\end{array}$ & $\begin{array}{l}\text { Andrews } \\
\text { and } \\
\text { Cingano } \\
(2014)\end{array}$ \\
\hline
\end{tabular}

Note: All the mentioned effects are statistically significant if not otherwise mentioned. The grey-shaded boxes indicate OECD-work. 


\section{Housing market policies}

\section{Which policies can best limit the build-up of vulnerabilities in the housing sector?}

46. Housing markets are a major source of financial instability and real estate booms and busts can have far reaching consequences, as recent experience has shown (e.g. Crowe et al. 2011). The main risks from housing market booms and busts are linked with increasing leverage both in the household and financial sector. Hence, policies to reduce the risks when housing prices are rapidly increasing need to focus on stemming the growth in house prices, lowering the build-up of debt, reducing risks in the composition of debt and making households and financial institutions more financially robust. On the demand side, monetary policy is one option. However, econometric estimates of interest rate effects on house prices are rather small (e.g. Kuttner, 2011), suggesting that to meaningfully restraint house-price growth interest rates would have to be increased substantially with possible large adverse effects for other sectors of the economy.

47. Macroprudential measures can help to restrain house price booms, however, as discussed in Section 4, the evidence of the effectiveness of macroprudential tools in dampening housing booms is not yet definitive. Given the limited data on the use of macroprudential policies, only a few papers have investigated their effects on housing markets. Using cross-country data on the use of macroprudential policies, Crowe et al. (2013) and Cerruti et al. (2015) find that loan-to-value (LTV) limits have the best chance to curb a real estate boom. On the other hand, Kuttner and Shim (2013), using a different dataset, find that capping the debt-service-to-income (DTI) ratios is more effective than adjusting the maximum loan-to-value ratio to slow credit growth during housing booms. They also find that restrictions targeting specific characteristics of loans have larger effects on mitigating credit growth than increasing capital requirements. A number of papers have investigated countries experiences with one or a few macroprudential policies. Jimenez et al. (2012) using micro-level data for Spain find that dynamic provisioning can help to tame credit supply, although it was not enough to stop the boom. Igan and Kang (2012) find that LTV and DTI limits appear to moderate mortgage credit growth in Korea.

48. House price reactions to demand shocks fundamentally depend on housing supply responses. Supply-side rigidities can prevent housing supply from adjusting in the face of increased demand putting additional pressure on prices. Policy measures aimed at increasing the responsiveness of housing supply such as streamlining cumbersome construction licensing procedures, designing and enforcing efficient land regulations, providing complimentary infrastructure and other public services or encouraging the use of land through better linking property values for tax purposes to market values - can help to avoid excessive increases and volatility in house prices (Andrews et al., 2011; Caldera and Johansson, 2013). However, the flipside is that in environments with very flexible housing supply, housing investment adjusts more rapidly to large changes in demand contributing to cyclical swings in economic growth (OECD, 2011).

49. A well-functioning and sufficiently large rental market can also help to reduce the pressure on house prices by allowing households to rent when house prices are rising relative to rents (André, 2010). A scarcity of rental housing driven by, for instance, tax systems biased towards homeownership or a tight regulation of rental markets, can lead to a decline in supply of rental accommodation preventing households from renting (Andrews et al., 2011).

\section{Housing policies: shock mitigation and recovery}

50. Housing policies also play a role in the adjustment to shocks through their impact on residential and labour mobility. Residential mobility decisions are strongly linked to housing market conditions at the local and national levels, which in turn are shaped by housing market policies. For instance, strict 
regulations in rental markets can reduce residential mobility as tenants in rent-controlled dwellings will be reluctant to move if rents are below market levels and tenure security is greater than in the unregulated rental market (e.g. Lind, 2001; Nagy, 1997; Ball, 2009). Overall, evidence by Caldera Sánchez and Andrews (2011) suggests that residential mobility is higher in countries with lower rent controls and tenant protection, lower transaction costs in buying a property, a more responsive housing supply, as well as greater access to credit. 
Table 7. Empirical evidence on the linkages between housing market policies and resilience

\begin{tabular}{|c|c|c|c|c|c|c|c|c|c|c|c|c|}
\hline Policy & Results & $\begin{array}{l}\text { Vulnerability } \\
\text { Method }\end{array}$ & Sample & Study & Results & $\begin{array}{l}\text { Resistance } \\
\text { Method }\end{array}$ & Sample & Study & Results & $\begin{array}{l}\text { Recovery } \\
\text { Method }\end{array}$ & Sample & Study \\
\hline $\begin{array}{l}\text { Housing } \\
\text { market } \\
\text { policies }\end{array}$ & $\begin{array}{l}\text { Asset market imbalances: } \\
\text { Less restrictive planning } \\
\text { regulations and rules on land } \\
\text { use increases the } \\
\text { responsiveness of housing } \\
\text { supply and the speed of } \\
\text { adjustment in the housing } \\
\text { markets. } \\
\text { Asset market imbalances: } \\
\begin{array}{l}\text { Higher housing supply } \\
\text { responsiveness and } \\
\text { transaction costs reduce real } \\
\text { house price variability. }\end{array}\end{array}$ & $\begin{array}{l}\text { Stock-flow } \\
\text { model } \\
\text { estimated } \\
\text { within an error } \\
\text { correction } \\
\text { framework } \\
\text { Panel } \\
\text { regressions } \\
\end{array}$ & $\begin{array}{l}20 \text { OECD } \\
\text { countries, } \\
\text { ca. } 1980- \\
2005\end{array}$ & $\begin{array}{l}\text { Caldera } \\
\text { Sanchez } \\
\text { - and } \\
\text { Johansson } \\
\text { (2013) } \\
\\
\text { Andrews et } \\
\text { al. (2011) }\end{array}$ & $\begin{array}{l}\text { Residential (and labour) } \\
\text { mobility is higher in countries } \\
\text { with lower transaction costs, } \\
\text { more responsive housing } \\
\text { supply, lower rent controls } \\
\text { and tenant protection, and } \\
\text { greater access to credit. }\end{array}$ & $\begin{array}{l}\text { Cross } \\
\text { country } \\
\text { regressions }\end{array}$ & $\begin{array}{l}25 \text { OECD } \\
\text { countries, } \\
2007\end{array}$ & $\begin{array}{l}\text { Caldera } \\
\text { Sanchez } \\
\text { and } \\
\text { Andrews } \\
\text { (2011) }\end{array}$ & $\begin{array}{l}\text { Elastic housing supply is } \\
\text { associated with bigger } \\
\text { housing stock overhangs, } \\
\text { making the required } \\
\text { adjustment bigger and } \\
\text { housing market recovery } \\
\text { longer. }\end{array}$ & $\begin{array}{l}\text { Panel } \\
\text { regressions }\end{array}$ & $\begin{array}{l}18 \\
\text { developed } \\
\text { countries, } \\
1990-2010\end{array}$ & $\begin{array}{l}\text { Bénétrix et } \\
\text { al. (2011) }\end{array}$ \\
\hline
\end{tabular}

Note: All the mentioned effects are statistically significant if not otherwise mentioned. The grey-shaded boxes indicate OECD-work. 
ECO/WKP(2015)69

\section{BIBLIOGRAPHY}

Aghion, P. and R. Griffith (2008), Competition and growth: reconciling theory and evidence, MIT Press

Aghion, P. and P. Howitt (1992), “A model of growth through creative destruction", Econometrica, Vol. 60/2, pp. 323-351, http://www.jstor.org/stable/2951599?seq=1\#page_scan_tab_contents

Ahrend, R., J. Arnold and C. Moeser (2011), "The Sharing of Macroeconomic Risk: Who Loses (and Gains) from Macroeconomic Shocks", OECD Economics Department Working Papers, No. 877, OECD Publishing, http://dx.doi.org/10.1787/5kg8hw5467wd-en

Ahrend, R., B. Cournède and R. W. Price (2008), "Monetary Policy, Market Excesses and Financial Turmoil”, OECD Economics Department Working Papers, No. 597, OECD Publishing, http://dx.doi.org/10.1787/244200148201

Ahrend, R. and A. Goujard (2012a), "International Capital Mobility and Financial Fragility - Part 3. How Do Structural Policies Affect Financial Crisis Risk?: Evidence from Past Crises Across OECD and Emerging Economies", OECD Economics Department Working Papers, No. 966, OECD Publishing, http://dx.doi.org/10.1787/5k97fmtj5vtk-en

Ahrend, R. and A. Goujard (2012b), "International Capital Mobility and Financial Fragility - Part 1. Drivers of Systemic Banking Crises: The Role of Bank-Balance-Sheet Contagion and Financial Account Structure", OECD Economics Department Working Papers, No. 902, OECD Publishing, http://dx.doi.org/10.1787/5kg3k8ksgglw-en

Ahrend, R., A. Goujard and C. Schwellnus (2012), "International Capital Mobility: Which Structural Policies Reduce Financial Fragility?", OECD Economic Policy Papers, No. 2, OECD Publishing, http://dx.doi.org/10.1787/5k97gkcv5z27-en

Alesina, A. and F. Giavazzi (eds.), (2013), Fiscal Policy after the Financial Crisis, The University of Chicago Press, http://papers.nber.org/books/ales11-1

Álvarez, L. and I. Hernando (2006), “Competition and Price Adjustment in the Euro Area”, Documentos de Trabajo, No. 0629,

http://www.bde.es/f/webbde/SES/Secciones/Publicaciones/PublicacionesSeriadas/DocumentosTraba jo/06/Fic/dt0629e.pdf

André, C. (2010), “A Bird's Eye View of OECD Housing Markets”, OECD Economics Department Working Papers, No. 746, OECD Publishing, http://dx.doi.org/10.1787/5kmlh5qvz1s4-en

Andrews, D., A. Caldera Sánchez and Å. Johansson (2011), "Housing Markets and Structural Policies in OECD Countries", OECD Economics Department Working Papers, No. 836, OECD Publishing, http://dx.doi.org/10.1787/5kgk8t2k9vf3-en 
Andrews, D. and F. Cingano (2014), "Resource allocation", Economic Policy, Vol. 29/78, http://onlinelibrary.wiley.com/doi/10.1111/1468-0327.12028/pdf

Asmussen, J. (2013), “The global crisis: lessons for international policy cooperation”, Speech at Kiel Institute for the World Economy, Kiel, 23 June 2013, http://www.ecb.europa.eu/press/key/date/2013/html/sp130623.en.html

Auerbach, A. and Y. Gorodnichenko (2012), "Measuring the Output Responses to Fiscal Policy", American Economic Journal: Economic Policy, Vol. 4/2, pp. 1-27, http://dx.doi.org/10.1257/pol.4.2.1

Babecký, J., et al. (2009), "Downward Nominal and Real Wage Rigidity - Survey Evidence for European Firms", ECB Woking Paper Series, No. 1105, http://www.ecb.europa.eu/pub/pdf/scpwps/ecbwp1105.pdf

Baldacci, E., S. Gupta and C. Mulas-Granados (2009), "How Effective is Fiscal Policy Response in Systemic Banking Crises?”, IMF Working Paper, No. 09/160, https://www.imf.org/external/pubs/ft/wp/2009/wp09160.pdf

Ball, M. (2009), European Housing Review, RICS (Royal Institution of Charted Surveyors), http://www.iut.nu/Facts\%20and\%20figures/RICS/2009EuropeanHousingReviewl.pdf

Bassanini, A. (2012), “Aggregate Earnings and Macroeconomic Shocks: The Role of Labour Market Policies and Institutions", IZA Discussion Paper Series, No. 6918, Institute for the Study of Labor, http://ftp.iza.org/dp6918.pdf

Bassanini, A. and R. Duval (2007), “The determinants of unemployment across OECD countries: Reassessing the role of policies and institutions", OECD Economic Studies, Vol. 2006/1, http://dx.doi.org/10.1787/eco_studies-v2006-art2-en

Bassanini, A. and R. Duval (2006), "Employment Patterns in OECD Countries: Reassessing the Role of Policies and Institutions", OECD Economics Department Working Papers, No. 486, OECD Publishing, http://dx.doi.org/10.1787/846627332717

Bassanini, A. and S. Scarpetta (2001), "The Driving Forces of Economic Growth: Panel Data Evidence for The OECD Countries", OECD Economic Studies, No. 33, http://www.oecd.org/eco/growth/18450995.pdf

Batini, N., G. Callegari and G. Melina (2012), "Successful Austerity in the United States, Europe and Japan", IMF Working Paper, No. 12/190, https://www.imf.org/external/pubs/ft/wp/2012/wp12190.pdf

Baumeister, C. and L. Benati (2010), "Unconventional Monetary Policy and the Great Recession. Estimating The Impact of a Compression in the Yield Spread at the Zero Lower Bound", ECB Working Paper Series, No. 1258, http://www.ecb.europa.eu/pub/pdf/scpwps/ecbwp1258.pdf

Bayoumi, T. (2014), "After the Fall: Lessons for Policy Cooperation from the Global Crisis", IMF Working Paper, No. 14/97, http://www.imf.org/external/pubs/ft/wp/2014/wp1497.pdf

Bayoumi, T., et al. (2014), "Monetary Policy in the New Normal", IMF Staff Discussion Note, SDN/14/3, https://www.imf.org/external/pubs/cat/longres.aspx?sk=41419 
Bean, C. (2003), “Asset prices, financial imbalances and monetary policy: are inflation targets enough?”, Bank for International Settlements Working Papers, No. 140, http://www.bis.org/publ/work140.pdf

Bech, M., L. Gambacorta and E. Kharroubi (2012), "Monetary policy in a downturn: Are financial crises special?", Bank for International Settlements Working Papers, No. 388, http://www.bis.org/publ/work388.htm

Bénétrix, A., B. Eichengreen and K. O’Rourke (2011), “How Housing Slumps End”, International Integration Studies Discussion Paper, No. 384, http://www.tcd.ie/iiis/documents/archive/discussion/pdfs/iiisdp384.pdf

Bernanke, B. (2011), "The Effects of the Great Recession on Central Bank Doctrine and Practice", Speech at the Federal Reserve Bank of Boston 56th Economic Conference, Boston, Massachusetts, October 18, 2011, Board of Governors of the Federal Reserve System, http://www.federalreserve.gov/newsevents/speech/bernanke20111018a.htm

Bertola, G. (1999), "Macroeconomic Perspectives on Aggregate Labor Markets", in Ashenfelter, O. and D. Card (eds.), Handbook of Labor Economics, Vol. 3C, Amsterdam: North-Holland

Bertola, G. and R. Rogerson (1997), "Institutions and labor reallocation", European Economic Review, Vol. 41/6, pp. 1147-1171, http://dx.doi.org/10.1016/S0014-2921(96)00048-7

Bini Smaghi, L. (2010), "What has the Financial Crisis Taught Us? The Global Dimension and International Policy Cooperation", Speech at 21 st Century Forum 2010, Beijing, 6-8 September 2010, http://www.ecb.europa.eu/press/key/date/2010/html/sp100907.en.html

BIS (2014), "Supervisory framework for measuring and controlling large exposures - final standard", Bank for International Settlements, http://www.bis.org/publ/bcbs283.htm

Blanchard, O. and D. Leigh (2013), "Growth Forecast Errors and Fiscal Multipliers", IMF Working Paper, No. 13/1, https://www.imf.org/external/pubs/cat/longres.aspx?sk=40200.0

Blanchard, O., G. Dell'Ariccia and P. Mauro (2010), "Rethinking Macroeconomic Policy", IMF Staff Position Note, SPN/10/03, https://www.imf.org/external/pubs/ft/spn/2010/spn1003.pdf

Blanchard, O. and J. Wolfers (2000) "The Role of Shocks and Institutions in the Rise of European Unemployment: the Aggregate Evidence", The Economic Journal, Vol. 110/462, http://dx.doi.org/10.1111/1468-0297.00518

Blanchard, O. (1999), European Unemployment: The Role of Shocks and Instititions, Banca d'Italia, https://www.bancaditalia.it/pubblicazioni/lezioni-baffi/pblecture05/index.html?com.dotmarketing.htmlpage.language $=1$

Blanchard, O. and L. Katz (1992), "Region al Evolutions", Brookings Papers on Economic Activity, Vol. 1, http://scholar.harvard.edu/lkatz/files/regional_evolutions.pdf

Blundell-Wignall, A. and P. Atkinson (2012), "Deleveraging, Traditional versus Capital Markets Banking and the Urgent Need to Separate and Recapitalise G-SIFI Banks", OECD Journal: Financial Market Trends, Vol. 2012/1, http://dx.doi.org/10.1787/fmt-2012-5k91hbvgfq20 
Blundell-Wignall, A. and C. Roulet (2013), "Macro-prudential policy, bank systemic risk and capital controls", OECD Journal: Financial Market Trends, Vol. 2013/2, http://dx.doi.org/10.1787/fmt2013-5jzb2rhkhks4

Borio, C. (2012), “The Financial Cycle and Macroeconomics: What Have We Learnt?”, Bank for International Settlements Working Papers, No. 395, http://www.bis.org/publ/work395.pdf

Borio, C. (2011), “Central banking post-crisis: What compass for uncharted waters?”, Bank for International Settlements Working Papers, No. 353, http://www.bis.org/publ/work353.pdf

Borio, C. and P. Disyatat (2010), "Unconventional monetary policies: an appraisal", The Manchester School, Vol. 78/s1, pp. 53-89, http://onlinelibrary.wiley.com/doi/10.1111/j.14679957.2010.02199.x/abstract

Bouis, R., et al. (2013), "The Effectiveness of Monetary Policy since the Onset of the Financial Crisis", OECD Economics Department Working Papers, No. 1081, OECD Publishing. http://dx.doi.org/10.1787/5k41zq9brrbr-en

Caballero, R. and M. Hammour (2005), "The Cost of Recessions Revisited: A Reverse-Liquidationist View", Review of Economic Studies, Vol. 72, pp. 313-41, http://www.jstor.org/stable/3700654

Caballero, R. and M. Hammour (1996),"On the Timing and Efficiency of Creative Destruction", The Quarterly Journal of Economics, Vol. 111/3, pp. 805-852, http://www.jstor.org/stable/2946673?seq=1\#page_scan_tab_contents

Caldera Sánchez, A. and D. Andrews (2011), "To Move or not to Move: What Drives Residential Mobility Rates in the OECD?", OECD Economics Department Working Papers, No. 846, OECD Publishing, http://dx.doi.org/10.1787/5kghtc7kzx21-en

Caldera Sánchez, A. and Å. Johansson (2013), “The Price Responsiveness of Housing Supply in OECD Countries", Journal of Housing Economics, Vol. 22/3, pp. 231-249, http://dx.doi.org/10.1016/j.jhe.2013.05.002

Canova, F., L. Coutinho and Z. Kontolemis (2012) "Measuring the macroeconomic resilience of industrial sectors in the EU and assessing the role of product market regulations", European Economy. Occasional Papers, No. 112, http://ec.europa.eu/economy_finance/publications/occasional_paper/2012/pdf/ocp112_en.pdf

Caruana, J. (2012), "Why central bank balance sheets matter", Bank for International Settlements Papers, No. 66b, http://www.bis.org/publ/bppdf/bispap66b.pdf

Case, K. and J. Quigley (2005), "Comparing Wealth Effects: The Stock Market versus the Housing Market", Advances in Macroeconomics, Vol. 5/1, http://escholarship.org/uc/item/28d3s92s\#page-2

Catte, P., N. Girouard, R. Price and C. André (2004), "Housing Markets, Wealth and the Business Cycle", OECD Economics Department Working Papers, No. 394, OECD Publishing, http://dx.doi.org/10.1787/534328100627

Cerra, V., U. Panizza and S. Saxena (2008), "International Evidence on Recovery from Recessions", IMF Working Papers, No. 09/183, http://www10.iadb.org/intal/intalcdi/PE/2009/03959.pdf 
Cerutti, E., S. Claessens and L. Laeven (2015), “The Use and Effectiveness of Macroprudential Policies: New Evidence", IMF Working Paper 15/64, March.

Chinn, M. and H. Ito (2008), "Global Current Account Imbalances: American Fiscal Policy versus East Asian Savings", Review of International Economics, Vol. 16/3, pp. 479-498, http://dx.doi.org/10.1111/j.1467-9396.2008.00741.x

Claessens, S. (2014), “An Overview of Macroprudential Policy Tools”, IMF Working Paper, No. 14/214, http://www.imf.org/external/pubs/ft/wp/2014/wp14214.pdf

Claessens, S., S. Ghosh and R. Mihet (2013), "Macro-prudential policies to mitigate financial system vulnerabilities", Journal of International Money and Finance, Vol. 39, pp. 153-185, http://dx.doi.org/.1016/j.jimonfin.2013.06.023

Coenen, G., et al. (2012), "Effects of Fiscal Stimulus in Structural Models", American Economic Journal: Macroeconomics, Vol. 4/1, pp. 22-68, http://dx.doi.org/10.1257/mac.4.1.22

Cottarelli, C., P. Gerson and A. Senhadji (eds.), Post-crisis Fiscal Policy, The MIT Press.

Corsetti, G., A. Meier and G. Müller (2012), “What Determines Government Spending Multipliers?”, IMF Working Paper, No. 12/150, https://www.imf.org/external/pubs/ft/wp/2012/wp12150.pdf

Cournède, B. and O. Denk (2014a), "The role of the financial sector for economic growth in OECD and G20 countries", OECD, ECO/CPE/WP1(2014)6.

Cournède, B. and O. Denk (2014b), "Finance and Inclusive Growth", OECD, ECO/CPE/WP1(2014)16.

Crowe, C. W., D. Igan, G. Dell'Ariccia, and P. Rabanal, 2011, "How to Deal with Real Estate Booms," IMF Staff Discussion Note 11/02.

Crowe, C., et al. (2013), "How to deal with real estate booms: Lessons from country experiences", Journal of Financial Stability, Vol. 9/3, pp. 300-319, http://dx.doi.org/10.1016/j.jfs.2013.05.003

Debrun, X., M. Gérard and J. Harris (2012): "Fiscal Policies in Crisis Mode: Has the Time for Fiscal Councils Come at Last?", Paper presented at the fourth annual meeting of OECD parliamentary budget officials and independent fiscal institutions, 23-24 February 2012, https://www1.oecd.org/gov/budgeting/49777890.pdf

Debrun, X. and R. Kapoor (2010), "Fiscal Policy and Macroeconomic Stability: Automatic Stabilizers Work, Always and Everywhere", IMF Working Paper, No. 10/111, https://www.imf.org/external/pubs/cat/longres.cfm?sk=23818.0

Decressin, J. and A. Fatás (1995), "Regional Labour Market Dynamics in Europe", European Economic Review,Vol. 39/9, pp. 1627-1655, http://dx.doi.org/10.1016/0014-2921(94)00102-2

Dell'Ariccia, G., D. Igan, L. Laeven and H. Tong (2013) "Policies for Macro-Financial Stability: Dealing with Credit Booms and Busts", in Claessens, S., M. Kose, L. Laeven and F. Valencia (eds.), Financial Crisis: Causes, Consequences, and Policy Responses, International Monetary Fund, pp. 325-365.

Dell'Ariccia, G., et al. (2012), "Policies for Macrofinancial Stability: How to Deal with Credit Booms", IMF Staff Discussion Notes, No. 12/6, https://www.imf.org/external/pubs/ft/sdn/2012/sdn1206.pdf 
Djankov, S. (2009), "Bankruptcy regimes during financial distress", World Bank Working Paper, No. 50322, http://documents.worldbank.org/curated/en/2009/05/11070939/bankruptcy-regimes-duringfinancial-distress

Dolls, M., C. Fuest and A. Peichl (2012), "Automatic stabilizers and economic crisis: US vs. Europe", Journal of Public Economics, Vol. 96, pp. 279-294, http://dx.doi.org/10.1016/j.jpubeco.2011.11.001

Duval, R., J. Elmeskov and L. Vogel (2007), "Structural Policies and Economic Resilience to Shocks", OECD Economics Department Working Papers, No. 567, OECD Publishing, http://dx.doi.org/10.1787/140152385131

Edwards, S. (2006), "Monetary unions, external shocks and economic performance: A Latin American perspective", International Economics and Economic Policy, Vol. 3, pp. 225-247, http://link.springer.com/article/10.1007/s10368-006-0056-2\#page-1

Eichengreen, B., et al. (2011), "Rethinking Central Banking", Committee on International Economic Policy and Reform, Brookings Institution,

http://www.brookings.edu/ /media/research/files/reports/2011/9/ciepr\%20central\%20banking/rethin king\%20central\%20banking.pdf

Eichengreen, B. (2011), "International Policy Coordination: The Long View”, NBER Working Paper Series, No. 17665, http://dx.doi.org/10.3386/w17665

Elekdag, S. and Y. Wu (2011), "Rapid Credit Growth: Boon or Boom-Bust?”, IMF Working Paper, No. 241.

Fall, F., et al. (2014), "Vulnerability of Social Institutions", OECD Economic Policy Papers, No. 11, OECD Publishing, http://dx.doi.org/10.1787/5jz158r4q0zn-en

Gambacorta, L., B. Hofmann and G. Peersman (2014), "The Effectiveness of Unconventional Monetary Policy at the Zero Lower Bound: A Cross-Country Analysis", Journal of Money, Credit and Banking, Vol. 46/4, pp. 615-642, http://dx.doi.org/10.1111/jmcb.12119

Galí, J., J. López-Salido and J. Vallés (2007), "Understanding the Effects of Government Spending on Consumption", Journal of the European Economic Association, Vol. 5/1, pp. 227-270, http://dx.doi.org/10.1162/JEEA.2007.5.1.227

Geroski, P. (1992), “Price Dynamics in UK Manufacturing: A Microeconomic View”, Economica, Vol. 59, pp. 403-419, http://www.jstor.org/stable/pdfplus/2554887.pdf?\&acceptTC=true\&jpdConfirm=true

Geroski, P. and S. Machin (1993), "Innovation, profitability and growth over the business cycle", Empirica, Vol. 20/1, pp. 35-50, http://link.springer.com/article/10.1007/BF01384139

Ghosh, A., et al. (2009), "Coping with the Crisis: Policy Options for Emerging Market Countries", IMF Staff Position Note, No. 09/08, http://www.imf.org/external/pubs/ft/spn/2009/spn0908.pdf

Gregg, P. and S. Machin (1999), "The Relationship Between Childhood Experiences, Subsequent Educational Attainment and Adult Labour Market Performance", http://personal.lse.ac.uk/machin/pdf/lux2000.pdf 
Hagemann, R. (2011), "How Can Fiscal Councils Strengthen Fiscal Performance?", OECD Journal: Economic Studies, Vol. 2011/1, http://dx.doi.org/10.1787/eco_studies-2011-5kg2d3gx4d5c

Hemmelgarn, T. and G. Nicodème (2010), “The 2008 Financial Crisis and Taxation Policy”, Taxation papers, No. 20,

http://ec.europa.eu/taxation_customs/resources/documents/taxation/gen_info/economic_analysis/tax _papers/taxation_paper_20_en.pdf

Hermansen, M. and O. Röhn (2015), "Resilience: The Usefulness of Early Warning Indicators in OECD Countries",OECD Economics Department Working Papers, No. 1250, OECD Publishing.

Hijzen, A. and S. Martin (2013), "The Role of Short-Time Work Schemes during the Global Financial Crisis and Early Recovery: A Cross-Country Analysis”, IZA Discussion Paper Series, No. 7291, http://ftp.iza.org/dp7291.pdf

Hong Kong Monetary Authority (2011), "Loan-to-value ratio as a macroprudential tool - Hong Kong SAR's experience and cross-country evidence", Bank for International Settlements Papers, No. 57k, http://www.bis.org/publ/bppdf/bispap57k.pdf

Igan, D., and H. Kang, 2011, "Do Loan-to-Value and Debt-to-Income Limits Work? Evidence from Korea," IMF Working paper 11/297.

in 't Veld, J., M. Larch and M. Vandeweyer (2012), "Automatic Fiscal Stabilisers: What they are and what they do", European Economy. Economic Papers, No. 452,

http://ec.europa.eu/economy_finance/publications/economic_paper/2012/pdf/ecp452_en.pdf

Ilzetzki, E., E. Mendoza and C. Végh (2011), “How Big (Small?) are Fiscal Multipliers?”, IMF Working Paper, No. 11/52, http://www.imf.org/external/pubs/ft/wp/2011/wp1152.pdf

IMF (2013), "The Interaction of Monetary and Macroprudential Policies", International Monetary Fund, https://www.imf.org/external/np/pp/eng/2013/012913.pdf

IMF (2012), "Dealing with Household Debt" in IMF, World Economic Outlook: Growth Resuming, Dangers Remain, International Monetary Fund, https://www.imf.org/external/pubs/ft/weo/2012/01/pdf/c3.pdf

IMF (2009), "From recession to recovery: How soon and how strong?", in IMF, World Economic Outlook, International Monetary Fund, pp. 103-138, https://www.imf.org/external/pubs/ft/weo/2009/01/pdf/c3.pdf

IMF (2008), "Fiscal Policy as a Countercyclical Tool," in IMF, World Economic Outlook, International Monetary Fund, pp. 160-196, http://www.imf.org/external/pubs/ft/weo/2008/02/pdf/text.pdf

Jiménez, Gabriel, Steven R. G. Ongena, Jose-Luis Peydro, and Jesus Saurina Salas, 2012, "Macroprudential Policy, Countercyclical Bank Capital Buffers and Credit Supply: Evidence from the Spanish Dynamic Provisioning Experiments," European Banking Center Discussion Paper 2012-011.

Jordà, Ò., M. Schularick and A. Taylor (2013), "When Credit Bites Back”, Journal of Money, Credit, and Banking, Vol. 45/2, http://dx.doi.org/10.1111/jmcb.12069 
Kannan, P., A. Scott and M. Terrones (2009), "From Recession to Recovery: How Soon and How Strong”, International Monetary Fund, https://www.imf.org/external/np/seminars/eng/2012/fincrises/pdf/ch8.pdf

Kerdrain, C., I. Koske and I. Wanner (2010), “The Impact of Structural Policies on Saving, Investment and Current Accounts”, OECD Economics Department Working Papers, No. 815, OECD Publishing, http://dx.doi.org/10.1787/5km398ttzlkg-en

Kuttner, K. N. (2011), “ Monetary Policy and Asset Price Volatility: Should we Refill the BernankeGertler Prescription?" in E. Kaufman and Malliaris (eds.). New Perspectives on Asset Price Bubbles: Theory, Evidence and Policy, Oxford: Oxford University Press.

Kuttner, K. N. and I. Shim (2013), "Can Non-Interest Rate Policies Stabilise Housing Markets? Evidence from a Panel of 57 Economies", BIS Working Paper No. 433.

Leigh, D. and S. Stehn (2009), "Fiscal and Monetary Policy During Downturns: Evidence from the G7", IMF Working Paper, No. 09/50, https://www.imf.org/external/pubs/ft/wp/2009/wp0950.pdf

Lim, C., et al. (2011), "Macroprudential Policy: What Instruments and How to Use Them? Lessons from Country Experiences", IMF Working Paper, No. 11/238, https://www.imf.org/external/pubs/cat/longres.aspx?sk=25296.0

Lind, H. (2001), "Rent Regulation: A Conceptual and Comparative Analysis", International Journal of Housing Policy, Vol. 1/1, pp. 41-57, http://www.tandfonline.com/doi/abs/10.1080/14616710110036436

Mineshima, A., M. Poplawski-Ribeiro and A. Weber (2014), "Size of Fiscal Multipliers", in Cottarelli, C., P. Gerson and A. Senhadji (eds.), Post-crisis Fiscal Policy, The MIT Press.

Mishkin, F. (2011) "Monetary Policy Strategy: Lessons from the Crisis", NBER Working Paper Series, No. 16755, http://dx.doi.org/10.3386/w16755

Mishkin, F. (2009) “Is Monetary Policy Effective During Financial Crises?”, NBER Working Paper Series, No. 14678, http://dx.doi.org/10.3386/w14678

Nagy, J. (1997), “Do Vacancy Decontrol Provisions Undo Rent Control?”, Journal of Urban Economics, Vol. 42/1, pp. 64-78, http://dx.doi.org/10.1006/juec.1996.2014

OECD (2014a), "New Approaches to Economic Challenges: The Financial Stream", OECD Publishing, http://www.oecd.org/mcm/NAEC-Finance-Stream-2014.pdf

OECD (2014b), OECD Economic Outlook, Vol. 2014/1, OECD Publishing, http://dx.doi.org/10.1787/eco_outlook-v2014-1-en

OECD (2014c), OECD Employment Outlook 2014, OECD Publishing, http://dx.doi.org/10.1787/empl_outlook-2014-en

OECD (2014d), Society at a Glance 2014: OECD Social Indicators, OECD Publishing, http://dx.doi.org/10.1787/soc_glance-2014-en

OECD (2013a), "Growth Prospects and Fiscal Requirements over the Long Term", in OECD, OECD Economic Outlook, Vol. 2013/1, OECD Publishing, http://dx.doi.org/10.1787/soc_glance-2014-en 
OECD (2013b), OECD Employment Outlook 2013, OECD Publishing, http://dx.doi.org/10.1787/empl_outlook-2013-en

OECD (2013c), "The OECD Action Plan for Youth - Giving Youth a Better Start in the Labour Market", http://www.oecd.org/employment/Action-plan-youth.pdf

OECD (2012), Economic Policy Reforms 2012: Going for Growth, OECD Publishing, http://dx.doi.org/10.1787/growth-2012-en

OECD (2011), "Housing and the Economy: Policies for Renovation", in OECD, Economic Policy Reforms 2011: Going for Growth, OECD Publishing, http://dx.doi.org/10.1787/growth-2011-46-en

OECD (2009a), "The Effectiveness and Scope of Fiscal Stimulus”, in OECD, OECD Economic Outlook, Interim Report March 2009, OECD Publishing,

http://dx.doi.org/10.1787/eco_outlook-v2008-sup2-16-en

OECD (2009b), “The Jobs Crisis: What Are the Implications for Employment and Social Policy?", in OECD, OECD Employment Outlook 2009: Tackling the Jobs Crisis, OECD Publishing, http://dx.doi.org/10.1787/empl_outlook-2009-2-en

Ostry, J. and A. Ghosh (2013), “Obstacles to International Policy Coordination, and How to Overcome Them”, IMF Staff Discussion Note, No. 13/11, https://www.imf.org/external/pubs/ft/sdn/2013/sdn1311.pdf

Pain, N. and O. Röhn (2011), "Policy Frameworks in the Post-Crisis Environment", OECD Economics Department Working Papers, No. 857, OECD Publishing, http://dx.doi.org/10.1787/5kgdpn1w9lkben

Price, R. and T. Dang (2011), “Adjusting Fiscal Balances for Asset Price Cycles”, OECD Economics Department Working Papers, No. 868, OECD Publishing, http://dx.doi.org/10.1787/5kgc42t3zqklen

Rawdanowicz, Ł., et al. (2015), "The Conduct of Monetary Policy in the New Normal: Instrument Use", OECD Economics Department Working Papers, forthcoming

Rawdanowicz, Ł., R. Bouis and S. Watanabe (2013), "The Benefits and Costs of Highly Expansionary Monetary Policy", OECD Economics Department Working Papers, No. 1082, OECD Publishing, http://dx.doi.org/10.1787/5k41zq81wj9v-en

Röhn, O. (2010), "New Evidence on the Private Saving Offset and Ricardian Equivalence", OECD Economics Department Working Papers, No. 762, OECD Publishing, http://dx.doi.org/10.1787/5kmft7qb5kq3-en

Röhn, O., A. Caldera Sánchez, M. Hermansen and M. Rasmussen (2015), "Economic Resilience: A New Set of Vulnerability Indicators for OECD Countries", OECD Economics Department Working Papers, No. 1249, OECD Publishing.

Schich, S., M. Bijlsma and R. Mocking (2014), "Improving the Monitoring of the Value of Implicit Guarantees For Bank Debt”, OECD Journal: Financial Market Trends, Vol. 2014/1, http://dx.doi.org/10.1787/fmt-2014-5jxzmkgjnt9x 
Schick, A. (2010), "Post-Crisis Fiscal Rules: Stabilising Public Finance while Responding to Economic Aftershocks", OECD Journal on Budgeting, Vol. 2010/2, http://www.oecd.org/gov/budgeting/48170224.pdf

Spilimbergo, A., et al. (2008), "Fiscal Policy for the Crisis", IMF Staff Position Note, SPN/08/01, https://www.imf.org/external/pubs/ft/spn/2008/spn0801.pdf

Svensson, L. (2012a), "Practical Monetary Policy: Examples from Sweden and the United States", NBER Working Paper Series, No. 17823, http://dx.doi.org/10.3386/w17823

Svensson, L. (2012b), "Differing Views on Monetary Policy", Speech at SNS/SIFR Finanspanel, Stockholm, 8 June 2012, BIS central bankers' speeches, http://www.bis.org/review/r120612c.pdf

Sullivan, D. and T. von Wachter (2009), "Job displacement and mortality: An analysis using administrative data”, The Quarterly Journal of Economics, Vol. 124/3, pp. 1265-1306, http://dx.doi.org/10.1162/qjec.2009.124.3.1265

Sutherland, D. and P. Hoeller (2013), "Growth-promoting Policies and Macroeconomic Stability", OECD Economics Department Working Papers, No. 1091, OECD Publishing, http://dx.doi.org/10.1787/5k3xqsz7c8d2-en

Sutherland, D. and P. Hoeller (2012), "Debt and Macroeconomic Stability: An Overview of the Literature and Some Empirics", OECD Economics Department Working Papers, No. 1006, OECD Publishing, http://dx.doi.org/10.1787/5k8xb75txzf5-en

Sutherland, D., et al. (2012), "Debt and Macroeconomic Stability", OECD Economics Department Working Papers, No. 1003, OECD Publishing, http://dx.doi.org/10.1787/5k8xb76rhstl-en

Sutherland, D., et al. (2010), "Counter-cyclical Economic Policy", OECD Economics Department Working Papers, No. 760, OECD Publishing, http://dx.doi.org/10.1787/5kmfw36tj97h-en

Taylor, J. (2011), "Macroeconomic Lessons from the Great Deviation”, in Acemoglu, D. and M. Woodford (eds.), NBER Macroeconomics Annual 2010, Vol. 25, pp. 387-395,

http://www.nber.org/chapters/c12042

van den Noord, P. (2005), "Tax incentives and house price volatility in the euro area: theory and evidence", Économie internationale, Vol. 1, pp. 29-45, http://www.cairn.info/revue-economieinternationale-2005-1-page-29.htm

van den Noord, P. (2000), "The Size and Role of Automatic Fiscal Stabilizers in the 1990s and Beyond", OECD Economics Department Working Papers, No. 230, OECD Publishing, http://dx.doi.org/10.1787/816628410134

White, W. (2009), “Should Monetary Policy “Lean or Clean"?", The Globalization and Monetary Policy Institute Working Papers, No. 34, Federal Reserve Bank of Dallas, http://www.dallasfed.org/assets/documents/institute/wpapers/2009/0034.pdf

Woodford, M. (2012), "Inflation Targeting and Financial Stability”, NBER Working Paper Series, No. 17967, http://dx.doi.org/10.3386/w17967

Ziebarth, N. (2012), "Misallocation and Productivity during the Great Depression", Mimeo, http://faculty.chicagobooth.edu/workshops/macro/past/pdf/productivity_dispersion.pdf

Ziemann, V. (2013), "Do Structural Policies Affect Macroeconomic Stability?", OECD Economics Department Working Papers, No. 1075, OECD Publishing, http://dx.doi.org/10.1787/5k43krfllgxten 
Table A1: Synthesis table on the linkages between policies and the different dimensions of resilience

\begin{tabular}{|c|c|c|c|}
\hline Policies & Vulnerability & Resistance & Recovery \\
\hline \multicolumn{4}{|c|}{ Monetary } \\
\hline & $\begin{array}{l}\text { Financial sector imbalances: Through the price of credit and } \\
\text { balance sheet policies, central banks influence risk-taking and } \\
\text { leverage in the financial sector. }\end{array}$ & $\begin{array}{l}\text { Expansionary monetary policy boosts aggregate demand through e.g. } \\
\text { lower interest rates and easier access to credit. }\end{array}$ & $\begin{array}{l}\text { Expansionary monetary policy shortens recessions through } \\
\text { increased demand, but is less effective in a financial crisis, when } \\
\text { private sector balance sheets and the monetary policy } \\
\text { transmission channel are impaired. }\end{array}$ \\
\hline & $\begin{array}{l}\text { Non-financial sector imbalances: The price of credit affects debt } \\
\text { levels of households and firms. }\end{array}$ & $\begin{array}{l}\text { Unconventional monetary policy measures can boost aggregate } \\
\text { demand when traditional monetary transmission channels are } \\
\text { impaired, e.g. because the policy rate is at the zero lower bound or } \\
\text { credit markets are frozen. }\end{array}$ & $\begin{array}{l}\text { Unconventional monetary policy measures can boost aggregate } \\
\text { demand when traditional monetary transmission channels are } \\
\text { impaired, e.g. because the policy rate is at the zero lower bound } \\
\text { or credit markets are frozen. }\end{array}$ \\
\hline & $\begin{array}{l}\text { Asset market imbalances: Through the price of credit central banks } \\
\text { can influence the build-up of asset price bubbles }\end{array}$ & & $\begin{array}{l}\text { Protracted monetary easing can delay balance sheet adjustments } \\
\text { in the private and public sectors slowing the recovery. }\end{array}$ \\
\hline \multicolumn{4}{|l|}{ Fiscal } \\
\hline & $\begin{array}{l}\text { Public sector imbalances: The fiscal stance influences debt } \\
\text { sustainability and solvency risk. }\end{array}$ & $\begin{array}{l}\text { Automatic stabilisers provide timely, targeted and temporary } \\
\text { stabilisation. }\end{array}$ & $\begin{array}{l}\text { Strong automatic stabilisers (e.g. progressive taxation and long- } \\
\text { lasting social benefits) can hurt growth. }\end{array}$ \\
\hline & $\begin{array}{l}\text { Public sector imbalances: Fiscal frameworks can assist fiscal policy } \\
\text { to become more sustainable, predictable and counter-cyclical and } \\
\text { reduce budgetary uncertainty. }\end{array}$ & $\begin{array}{l}\text { Expenditure rules may help to build up fiscal reserves in boom periods } \\
\text { creating more fiscal space in downturns. }\end{array}$ & \\
\hline & $\begin{array}{l}\text { External sector imbalances: Changes in the government budget } \\
\text { balance will alter total saving and thereby the current account, } \\
\text { reflecting evidence that Ricardian equivalence only holds partially. }\end{array}$ & $\begin{array}{l}\text { Discretionary fiscal policy can boost aggregate demand in the short } \\
\text { run. Under normal circumstances, the largest short-run impact on } \\
\text { aggregate demand is likely to come from government spending }\end{array}$ & $\begin{array}{l}\text { Discretionary fiscal policy can boost aggregate demand in the } \\
\text { short run and strengthen the recovery. Under normal } \\
\text { circumstances, the largest short-run impact on aggregate }\end{array}$ \\
\hline & $\begin{array}{l}\text { External sector imbalances: Social spending (in particular on health } \\
\text { care) affects the saving rate through precautionary savings influencing } \\
\text { the current account. }\end{array}$ & $\begin{array}{l}\text { measures rather than those related to transters or tax cuts. FIscal } \\
\text { multipliers are larger when monetary policy is constrained by the zero } \\
\text { lower bound on nominal interest rates;, the channels of monetary } \\
\text { policy are impeded by a weak financial sector; or the economy is in a } \\
\text { recession. }\end{array}$ & $\begin{array}{l}\text { demand is likely to come from government spending measures } \\
\text { rather than those related to transfers or tax cuts. }\end{array}$ \\
\hline \multicolumn{4}{|c|}{ Financial market } \\
\hline & $\begin{array}{l}\text { Financial sector imbalances: Micro- and macroprudential measures } \\
\text { (e.g. countercyclical capital buffers) can increase the shock absorption } \\
\text { capacity and reduce the pro-cyclicality of the financial sector. Liquidity } \\
\text { regulations can reduce excessive maturity mismatch. }\end{array}$ & $\begin{array}{l}\text { Regulations to build-up bank capital buffers make banks more robust } \\
\text { to shocks, thus facilitating lending. }\end{array}$ & \\
\hline & $\begin{array}{l}\text { Non-financial sector imbalances: Targeted micro- and } \\
\text { macroprudential measures (e.g. debt-to-income ratios) can impose } \\
\text { additional lending costs to certain sectors of the economy, reducing } \\
\text { credit growth and debt build-up. }\end{array}$ & $\begin{array}{l}\text { Regulations requiring banks to hold sufficient high quality and liquid } \\
\text { assets reduce the risk of fire-sales and that liquidity problems turn into } \\
\text { solvency problems. }\end{array}$ & \\
\hline & $\begin{array}{l}\text { Asset market imbalances: Macroprudential measures (e.g. Ioan-to- } \\
\text { value ratios) can curb excessive leverage and mitigate asset price } \\
\text { booms. }\end{array}$ & & \\
\hline & $\begin{array}{l}\text { Financial and public sector imbalances: Explicit and implicit public } \\
\text { guarantees (e.g. for too-big-to-fail institutions) may induce moral } \\
\text { hazard leading to overly risky lending and adverse feedback loops } \\
\text { between sovereign and banks. }\end{array}$ & & \\
\hline
\end{tabular}


ECO/WKP(2015)69

\begin{tabular}{|c|c|c|c|}
\hline Policies & Vulnerability & Resistance & Recovery \\
\hline \multicolumn{4}{|l|}{ Taxation } \\
\hline \multirow[t]{3}{*}{+2} & $\begin{array}{l}\text { Financial and non-financial sector imbalances: Tax systems with a } \\
\text { debt bias increase firms and households (e.g. mortgage interest tax } \\
\text { relief) leverage. }\end{array}$ & & $\begin{array}{l}\text { Tax systems with a debt bias increase firms' leverage ratios. This } \\
\text { can create debt overhang problems delaying the recovery. }\end{array}$ \\
\hline & $\begin{array}{l}\text { Asset market imbalances: Favourable tax treatment of housing } \\
\text { encourages excessive mortgage borrowing fuelling housing price } \\
\text { booms. }\end{array}$ & $\begin{array}{l}\text { Subsidising homeownership (e.g. favourable tax treatment) increases } \\
\text { house price volatility making a house price bust more severe. }\end{array}$ & $\begin{array}{l}\text { Favourable tax treatment of housing encourages excessive } \\
\text { mortgage borrowing. At high levels of household debt, } \\
\text { households may be forced to deleverage delaying the recovery. }\end{array}$ \\
\hline & $\begin{array}{l}\text { Financial sector imbalances: Executive compensation packages } \\
\text { including bonuses and stock options that benefit from tax preferences } \\
\text { can induce excessive risk taking. }\end{array}$ & & $\begin{array}{l}\text { Tax incentives to homeownership increase the share of } \\
\text { homeowners. To the extent that homeowners are less likely to } \\
\text { migrate than tenants, tax incentives that favour homeownership } \\
\text { reduce geographical labour mobility. }\end{array}$ \\
\hline \multicolumn{4}{|c|}{ Labour market } \\
\hline & $\begin{array}{l}\text { External sector imbalances: Stricter employment protection } \\
\text { legislation (EPL) is associated with higher investments (due to greater } \\
\text { substitution of capital for labour), but lower saving rates weakening the } \\
\text { current account. }\end{array}$ & $\begin{array}{l}\text { Strict ELP cushions the shock impact on unemployment by deterring } \\
\text { firms from laying off workers. A large gap in job protection between } \\
\text { permanent and temporary workers generates high unemployment } \\
\text { turnover and insecurity for temporary workers. }\end{array}$ & $\begin{array}{l}\text { Employment protection provisions whose costs are high hinder } \\
\text { hiring and risk increasing unemployment persistence. } \\
\text { High firing costs slow down the wage adjustment process as well } \\
\text { as workers' reallocation towards more productive jobs. }\end{array}$ \\
\hline & & $\begin{array}{l}\text { Minimum wages can prevent nominal wages at the lower end of the } \\
\text { distribution from bearing the brunt of adjustment to a shock. However, } \\
\text { high and, especially, far reaching statutory minimum wages have had } \\
\text { adverse impacts on youth employment and unemployment in the wake } \\
\text { of numerous macroeconomic shocks. }\end{array}$ & $\begin{array}{l}\text { High statutory minimum wages can slow wage adjustments in the } \\
\text { aftermath of an adverse shock. }\end{array}$ \\
\hline & & & $\begin{array}{l}\text { A high degree of centralisation and/or coordination of wage } \\
\text { bargaining speeds up wage adjustment to adverse shocks. }\end{array}$ \\
\hline & & & $\begin{array}{l}\text { In centralised bargaining systems wage adjustment may be } \\
\text { difficult if shocks are persistent and heterogeneous across the } \\
\text { economy. }\end{array}$ \\
\hline & & $\begin{array}{l}\text { Short time work schemes (STW) can cushion the impact of output } \\
\text { shocks on employment by allowing each employee to work less. }\end{array}$ & $\begin{array}{l}\text { Poorly-designed STW schemes (e.g. too broad and/or stay in } \\
\text { place too long) can impede structural change and slow the } \\
\text { recovery. }\end{array}$ \\
\hline & & $\begin{array}{l}\text { High replacement rates, broad coverage and long-lasting } \\
\text { unemployment benefits mitigate a decline in households' disposable } \\
\text { income. }\end{array}$ & $\begin{array}{l}\text { High and long-lasting unemployment benefits can slow the } \\
\text { recovery by weakening job-search prolonging unemployment } \\
\text { spells and persistency. }\end{array}$ \\
\hline & & & $\begin{array}{l}\text { Effective active labour market policies can reduce unemployment } \\
\text { persistence by improving job matching and increasing the labour } \\
\text { market influence of outsiders on wages. }\end{array}$ \\
\hline & & $\begin{array}{l}\text { Easier access to early retirement, long-term sickness and disability } \\
\text { schemes may mitigate the impact of an adverse shock on disposable } \\
\text { income. }\end{array}$ & $\begin{array}{l}\text { Once in early retirement, long-term sickness or disability } \\
\text { schemes workers are unlikely to re-enter the labour force leading } \\
\text { to a permanent fall in labour supply. }\end{array}$ \\
\hline
\end{tabular}


ECO/WKP(2015)69

\begin{tabular}{|c|c|c|c|}
\hline Policies & Vulnerability & Resistance & $\begin{array}{r}\text { Recovery } \\
\text { Recis }\end{array}$ \\
\hline \multicolumn{4}{|l|}{ Product market } \\
\hline & $\begin{array}{l}\text { External market imbalances: Rigid product market regulations } \\
\text { (PMR) impose costs and create barriers to entry making it less } \\
\text { attractive and more difficult to invest in a country. This reduces foreign } \\
\text { direct investment resulting in an increased bias of external liabilities } \\
\text { towards debt. }\end{array}$ & $\begin{array}{l}\text { Lower competition (e.g. via strict product market regulation) creates } \\
\text { rents that allow firms to minimise lay-offs in the short run, as they can } \\
\text { squeeze mark-ups. }\end{array}$ & $\begin{array}{l}\text { Pro-competitive PMR speeds the economic recovery by enabling } \\
\text { a quicker and more efficient reallocation of resources within and } \\
\text { across sectors and firms when face by a shock }\end{array}$ \\
\hline & $\begin{array}{l}\text { External sector imbalances: PMR liberalisation temporarily boosts } \\
\text { investment which temporarily weakens the current account. }\end{array}$ & & $\begin{array}{l}\text { Pro-competitive PMR speeds the economic recovery by } \\
\text { strengthening firms incentives to adopt more efficient and flexible } \\
\text { production techniques }\end{array}$ \\
\hline & & & $\begin{array}{l}\text { Pro-competitive PMR speeds the economic recovery by } \\
\text { strengthening firms' incentives to innovate when faced by a } \\
\text { shock. }\end{array}$ \\
\hline \multicolumn{4}{|l|}{$\begin{array}{l}\text { Bankruptcy } \\
\text { system }\end{array}$} \\
\hline & & & $\begin{array}{l}\text { Well-designed bankruptcy systems can foster an efficient } \\
\text { reallocation of resources by reducing the likelihood that } \\
\text { resources are trapped in inefficient firms. }\end{array}$ \\
\hline \multicolumn{4}{|l|}{ Housing policies } \\
\hline & $\begin{array}{l}\text { Asset market imbalances: Measures to increase housing supply } \\
\text { elasticity reduce excessive price volatility by helping supply to equal } \\
\text { demand. However, with very flexible housing supply, housing } \\
\text { investments adjust rapidly to changes in demand contributing to GDP } \\
\text { volatility. }\end{array}$ & & $\begin{array}{l}\text { Housing policies affect residential and labour mobility. For } \\
\text { example, excessive rental regulation gives tenants negative } \\
\text { incentives to move. Inelastic housing supply increases regional } \\
\text { housing price differences making it less affordable to move from } \\
\text { a region with low prices to one with high prices. }\end{array}$ \\
\hline
\end{tabular}

